\title{
Catalysts for Hydrogen Generation via Oxy-Steam Reforming of Methanol Process
}

\author{
Magdalena Mosińska, Małgorzata I. Szynkowska-Jóźwik (1) and Paweł Mierczyński *(i) \\ Institute of General and Ecological Chemistry, Lodz University of Technology, Zeromskiego 116, \\ 90-924 Lodz, Poland; magdalena.mosinska@dokt.p.lodz.pl (M.M.); malgorzata.szynkowska@p.lodz.pl (M.I.S.-J.) \\ * Correspondence: pawel.mierczynski@p.lodz.pl; Tel.: +48-426313125
}

Received: 23 October 2020; Accepted: 1 December 2020; Published: 8 December 2020

\begin{abstract}
The production of pure hydrogen is one of the most important problems of the modern chemical industry. While high volume production of hydrogen is well under control, finding a cheap method of hydrogen production for small, mobile, or his receivers, such as fuel cells or hybrid cars, is still a problem. Potentially, a promising method for the generation of hydrogen can be oxy-steam-reforming of methanol process. It is a process that takes place at relatively low temperature and atmospheric pressure, which makes it possible to generate hydrogen directly where it is needed. It is a process that takes place at relatively low temperature and atmospheric pressure, which makes it possible to generate hydrogen directly where it is needed. This paper summarizes the current state of knowledge on the catalysts used for the production of hydrogen in the process of the oxy-steam-reforming of methanol (OSRM). The development of innovative energy generation technologies has intensified research related to the design of new catalysts that can be used in methanol-reforming reactions. This review shows the different pathways of the methanol-reforming reaction. The paper presents a comparison of commonly used copper-based catalysts with other catalytic systems for the production of $\mathrm{H}_{2}$ via OSRM reaction. The surface mechanism of the oxy-steam-reforming of methanol and the kinetic model of the OSRM process are discussed.
\end{abstract}

Keywords: hydrogen production; oxy-steam-reforming of methanol; heterogeneous catalysts; surface reaction mechanism

\section{Introduction}

The economic and civilization development of the world has caused the population and the total energy consumption to have increased significantly recently. The current state of the natural environment and the shrinking reserves of crude oil, resulting from excessive consumption of fossil fuels, have intensified research related to the use of alternative fuels and energy generation technologies [1]. The use of fossil fuels has a negative impact on the environment and causes the emission of harmful oxides into the atmosphere. The emission of an excessive amount of harmful gases into the atmosphere is responsible for the formation of smog and the greenhouse effect. This is a serious problem for animals, plants and human health [2]. In addition, it should be emphasized that fossil fuel sources are not renewable. Their continuous exploitation may finally lead to the exhaustion of their sources. The greatest challenge nowadays is the production of energy from renewable sources. One of the promising alternatives to fossil fuels is hydrogen [3]. Hydrogen is a pro-environmental energy carrier. In the burning flame arise only water vapor and nitrogen oxides, and when the oxidation process is carried out in fuel cells, the only byproduct is water vapor. Hydrogen also has a low ignition energy of initiation, which improves combustion. It is worth noting that the sources of hydrogen are practically inexhaustible. The increased interest in hydrogen is also associated with its usage to 
power fuel cells as one of the possible alternatives to replace fossil fuels [4,5]. Current research proves that the use of hydrogen to power fuel cells is one of the most effective and environmentally friendly technologies of transforming chemical energy into electricity, which does not generate additional pollution [5,6]. Hydrogen and fuel cell are a great opportunity to reduce emissions of compounds such as nitrogen oxides, carbon oxides, various hydrocarbons, which cause acid rain and possibly the greenhouse effect. The utilization of hydrogen and fuel cells can eliminate the formation of smog in highly urbanized cities. In addition, due to the fact that hydrogen used to power fuel cells should be highly pure, because small amounts of carbon monoxide (above $10 \mathrm{ppm}$ ) in the gas supplying the fuel cell cause its irreversible adsorption and poisoning of platinum electrodes used in fuel cells [7]. Therefore, the key task seems to be the development of a method or technology for the production of high purity hydrogen. The production of pure hydrogen is an important problem in the modern chemical industry. However, the industrial production of hydrogen-based on natural gas reforming is well known; it is still a problem to find low-cost methods for obtaining hydrogen intended for supplying small or mobile devices, such as fuel cells. High efficiency, durability and reliability of fuel cell technology represents a major potential, pointing to the possibility of the rapid development of industries that use fuel cells. The possible ways of hydrogen generation and application are presented in Figure 1. There are many sources of hydrogen that can include hydrocarbons, alcohols, ammonia and others. However, methanol is one of the most promising sources of hydrogen because it is the simplest alcohol without a $\mathrm{C}-\mathrm{C}$ bond in the molecule and provides a high $\mathrm{H}: \mathrm{C}$ ratio in a molecule. Its properties indicate that methanol can be easily reformable in the low-temperature range and under atmospheric pressure. Considering the relatively mild conditions of the methanol-reforming process $(p=1 \mathrm{~atm}$, $\mathrm{T}=160-350^{\circ} \mathrm{C}$ ), it is possible to generate hydrogen practically everywhere. Production of hydrogen through mixed oxy-steam-reforming of methanol enables to be carried out the process autothermally, which is extremely beneficial from the economics point of view.

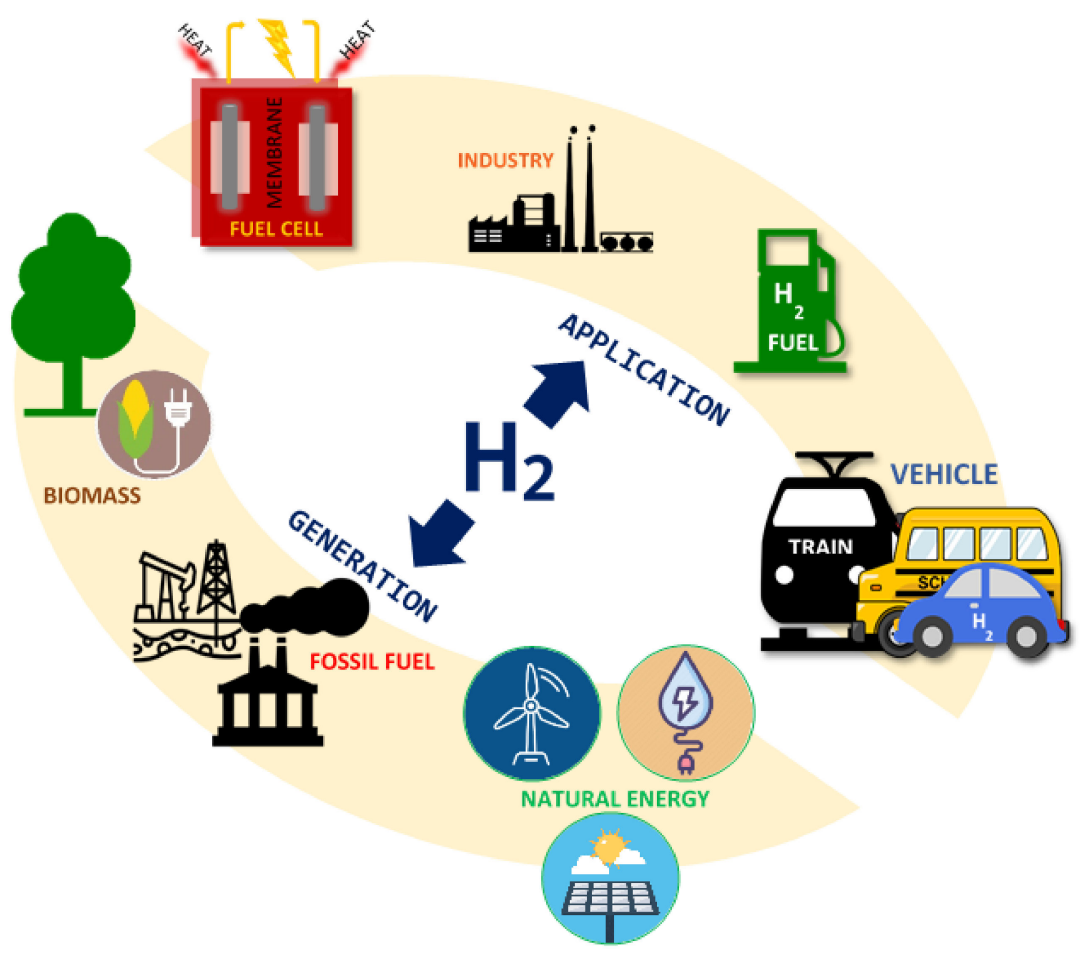

Figure 1. Hydrogen as an energy carrier.

Methanol fuel cell DMFC (direct methanol fuel cell) is particularly promising. The choice of methanol as a fuel is dictated by the high energy density of methanol and relatively easy oxidation of methanol at a relatively low temperature of $40-80^{\circ} \mathrm{C}$. The principle of operation of a methanol-powered 
fuel cell is shown in Figure 2. One of the most important applications of fuel cell technology is hybrid systems, which are widely used in the first commercial portable power generators and prototype electric vehicles [8]. Portable power generators are based on a methanol fuel cell (direct or generators equipped with a micro-reformer) [9] and lithium-ion battery. Prototype mobile vehicles use nickel-hydride battery used for starting purposes or for maintaining stable engine operation. These vehicles achieve an efficiency of about $50 \%$, which is a value higher than in hybrid cars equipped with internal combustion engines. The disadvantage of these systems is their present cost, which is difficult to reduce [9]. The basic condition that hydrogen could replace current energy sources is to develop a cheap, efficient and rapid method for hydrogen production.

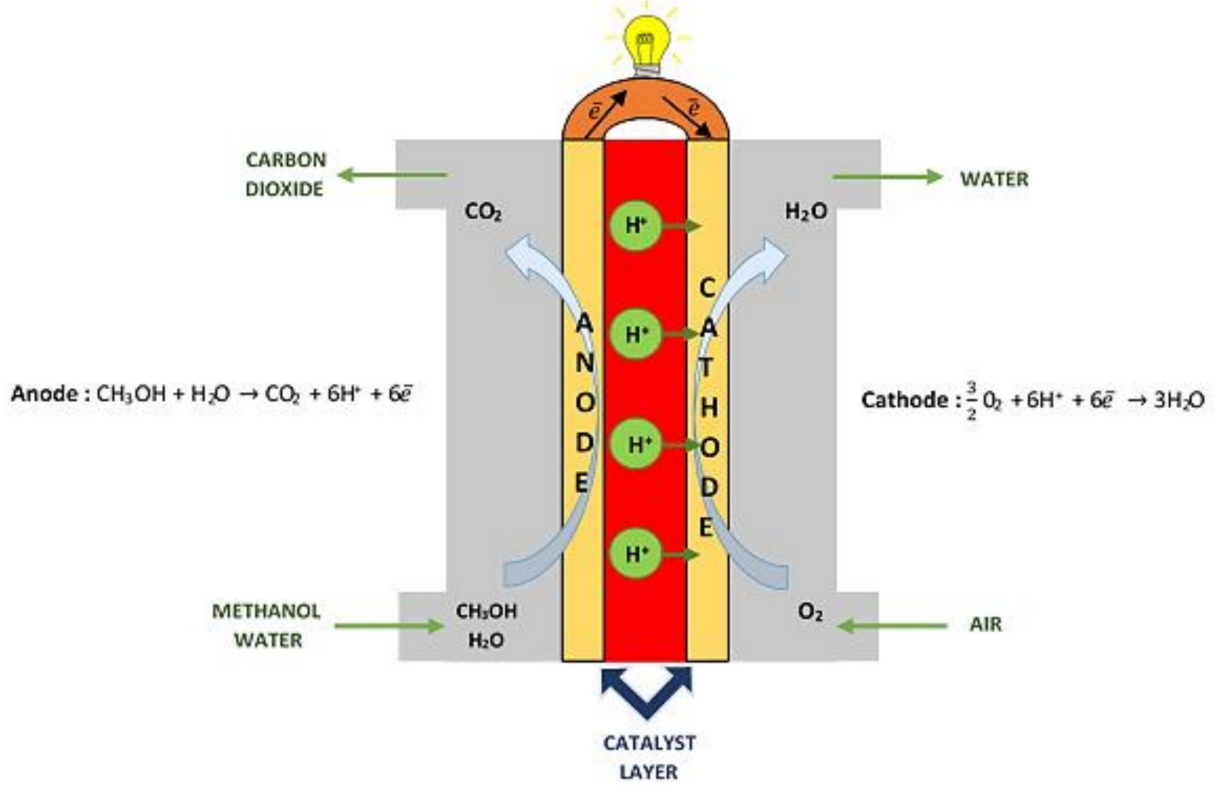

Figure 2. Direct methanol fuel cells (DMFC).

The importance of hydrogen as a fuel in the twenty-first century still increases with the further development of fuel cells, which are used in automotive, power generation, power supplies, cell phones and laptops. Due to the above reasons, one of the most important areas of the research in the field of hydrogen production, which are undertaken by scientific groups around the world, is the design of new catalytic systems, which must be characterized by high activity and selectivity in the reforming of methanol reaction. An important aspect of the developed catalysts is their high stability, which they should have in order to be used to power fuel cells applied in mobile vehicles or stationary systems constituting an emergency energy source in public places (including military bases, offices, hospitals, administrative buildings, etc.). Their applicability increases due to their quiet operation, the quality of the supplied energy, the possibility to transport and application practically everywhere.

\section{Methanol Reforming Reactions}

There are many possible sources of hydrogen that can include hydrocarbons, alcohols, ammonia and others [5,10-16]. An attractive alternative solution to problems associated with storing molecular hydrogen involves on board catalytic production of hydrogen from a high energy liquid fuel such as methanol. Methanol is one of the most promising sources of hydrogen because it is the simplest alcohol without a $\mathrm{C}-\mathrm{C}$ bond in the molecule and provides a high $\mathrm{H}: \mathrm{C}$ ratio in a molecule. Its properties indicate that methanol can be easily decomposed to a hydrogen-rich mixture practically everywhere. The hydrogen can be synthesized from the catalytic reforming of methanol, decomposition of methanol, partial oxidation of methanol, or a combination of two processes into one reaction, which is named the oxy-steam-reforming of methanol $[4,17-21]$. Thermodynamics of the processes of partial oxidation and 
steam-reforming of methanol suggests that the most energetically favorable solution is a combination of these two reactions in one process. Depending on the stoichiometry of the reaction between methanol, water vapor and oxygen, the methanol processing reactions run according to the following equations: Steam reforming of methanol (SRM)

$$
\mathrm{CH}_{3} \mathrm{OH}+\mathrm{H}_{2} \mathrm{O} \rightarrow \mathrm{CO}_{2}+3 \mathrm{H}_{2} \Delta \mathrm{H}^{\circ}=49.7 \mathrm{~kJ} / \mathrm{mol}
$$

Decomposition of methanol (MD)

$$
\mathrm{CH}_{3} \mathrm{OH} \rightarrow \mathrm{CO}+2 \mathrm{H}_{2} \Delta \mathrm{H}^{\circ}=128.5 \mathrm{~kJ} / \mathrm{mol}
$$

Partial oxidation of methanol (POM)

$$
\mathrm{CH}_{3} \mathrm{OH}+0.5 \mathrm{O}_{2} \rightarrow \mathrm{CO}_{2}+2 \mathrm{H}_{2} \Delta \mathrm{H}^{\circ}=-192.2 \mathrm{~kJ} / \mathrm{mol}
$$

Oxy-Steam Reforming of Methanol (OSRM-a combination of SRM and POM)

$$
\mathrm{CH}_{3} \mathrm{OH}+0.5 \mathrm{H}_{2} \mathrm{O}+0.25 \mathrm{O}_{2} \rightarrow \mathrm{CO}_{2}+2.5 \mathrm{H}_{2} \Delta \mathrm{H}^{\circ}=-71.4 \mathrm{~kJ} / \mathrm{mol}
$$

It is worth emphasizing that the most energetically beneficial process is oxy-steam-reforming of methanol being a combination of steam and partial oxidation of methanol in one process. In addition, this process can be carried out at low temperature $\left(160-350^{\circ} \mathrm{C}\right)$ at atmospheric pressure without the formation of carbon deposits $[18,22,23]$. This means that hydrogen can be directly produced where it is needed. The production of hydrogen by the oxy-steam-reforming methanol method allows the reaction to be carried out in an auto-thermal way, which is very beneficial from an economic point of view. The supported catalysts used in this reaction undergo deactivation process due to carbon deposition or as a result of overheating. The problem is obtaining pure hydrogen without carbon monoxide. $\mathrm{CO}$ is a strong poison of platinum catalyst used directly in fuel cells.

Geissler et al. [24] developed the kinetic model for the autothermal reforming of methanol reaction over $\mathrm{CuO} / \mathrm{ZnO} / \mathrm{Al}_{2} \mathrm{O}_{3}$ catalyst. They reported that the eight possible reactions take place during the autothermal reforming of the methanol process, and seven components were present in the feed or product gases of the reaction (see Figure 3). The reaction scheme showed that the reactions strongly depend on each other because most of the components occur in more than one reaction. In addition, the products of one reaction can be reactants in other reactions. All reactions which run in the presence of oxygen are very fast and strongly exothermic compared to the reverse water gas shift (RWGS) process. This result proves that the major source of hydrogen is the steam-reforming of methanol reaction. Moreover, the dimethyl ether (DME) formation can be considered independently from the other reactions, which runs parallel with another autothermal reforming of methanol reactions. The reactor to autothermal reforming of methanol process is divided into two parts. Strongly exothermic reactions with oxygen take place at the entrance to the reactor. In the lower parts of the catalyst bed, the endothermic reactions, including mainly steam-reforming of methanol, are carried out. Furthermore, two models of autothermal reforming reactions (ATRM) can be considered, named partial oxidation-steam-reforming of methanol (POM-SRM) and total oxidation-steam-reforming of methanol (TOM-SRM). The coefficients describing the number of reactants, which must be taken for the mentioned processes of the methanol processing, are shown in Table 1. The experimental analysis clearly showed that in the presence of oxygen, the methanol conversion occurs mainly via the total oxidation (TOM) reaction. However, the hydrogen production is subsequent to the steam-reforming (SRM) reaction. 


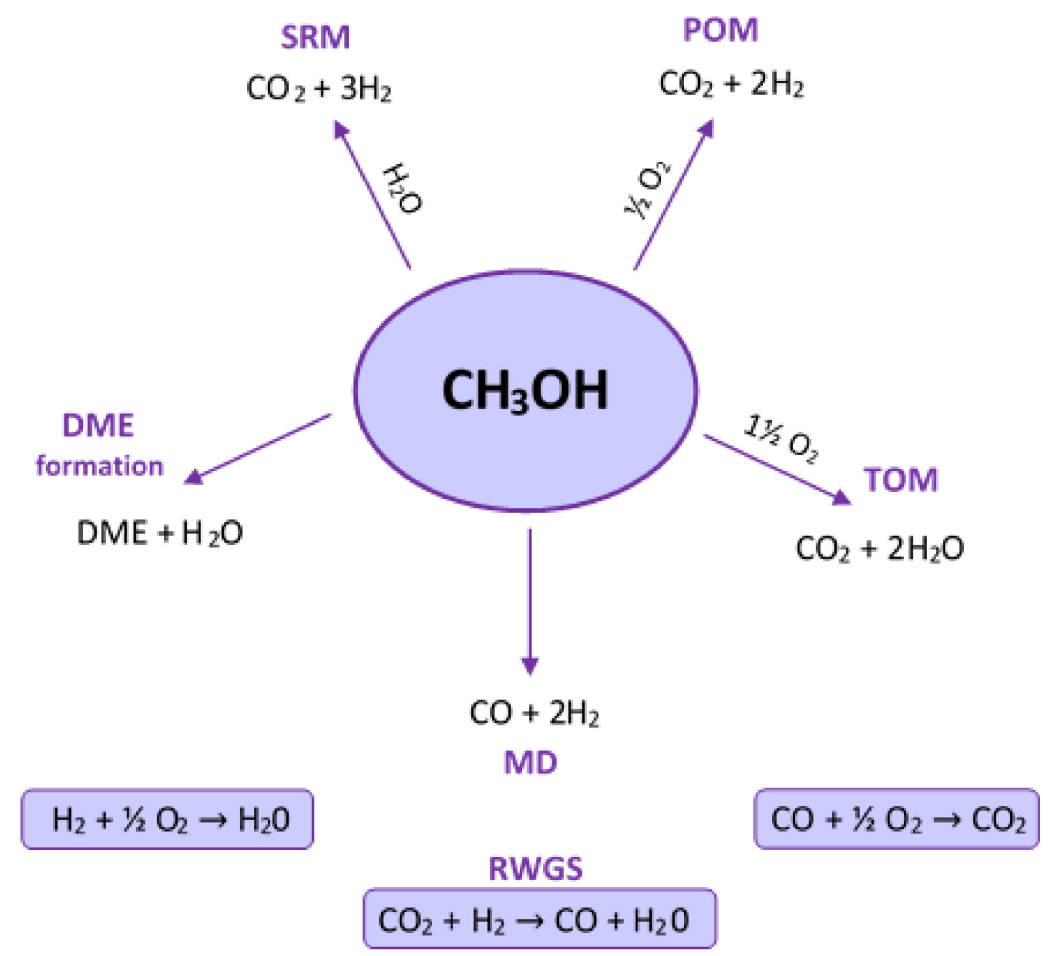

Figure 3. The possible reactions for the autothermal reforming of methanol process [24].

Table 1. The coefficients of combination for two models of autothermal reforming of methanol process (ATRM) [24].

\begin{tabular}{cccc}
\hline & & POM-SRM & TOM-SRM \\
\hline SRM & $\mathrm{CH}_{3} \mathrm{OH}+\mathrm{H}_{2} \mathrm{O} \rightarrow \mathrm{CO}_{2}+3 \mathrm{H}_{2}$ & 3 & $3 \frac{2}{3}$ \\
\hline POM & $\mathrm{CH}_{3} \mathrm{OH}+\frac{1}{2} \mathrm{O}_{2} \rightarrow \mathrm{CO}_{2}+2 \mathrm{H}_{2}$ & 1 & - \\
\hline TOM & $\mathrm{CH}_{3} \mathrm{OH}+\frac{3}{2} \mathrm{O}_{2} \rightarrow \mathrm{CO}_{2}+2 \mathrm{H}_{2} \mathrm{O}$ & - & $\frac{1}{3}$ \\
\hline$\sum$ ATRM & $4 \mathrm{CH}_{3} \mathrm{OH}+3 \mathrm{H}_{2} \mathrm{O}+\frac{1}{2} \mathrm{O}_{2}+2 \mathrm{~N}_{2} \rightarrow 4 \mathrm{CO}_{2}+11 \mathrm{H}_{2}+2 \mathrm{~N}_{2}$ & & \\
\hline
\end{tabular}

\section{Surface Reaction Mechanism and Kinetic Models of the Oxy-Steam Reforming of Methanol Process on Copper-Based System}

The literature review concerning the catalysts used in the steam, partial oxidation and oxy-steamreforming of methanol reactions shows that the typical catalysts of the discussed processes are copper catalysts supported on both monoxides: $\mathrm{Al}_{2} \mathrm{O}_{3}, \mathrm{ZnO}, \mathrm{CeO}_{2}, \mathrm{MgO}, \mathrm{La}_{2} \mathrm{O}_{3}, \mathrm{SiO}_{2}$, and bi-oxides: $\mathrm{ZnO}-\mathrm{Al}_{2} \mathrm{O}_{3}, \mathrm{CeO}_{2}-\mathrm{ZrO}_{2}, \mathrm{SiO}_{2}-\mathrm{SnO}_{2}, \mathrm{Al}_{2} \mathrm{O}_{3}-\mathrm{CeO}_{2}$ [18,25-38]. Metallic copper surface determined by the chemisorption method, high values of copper dispersion is the targets to attain for the achievement of highly active catalysts. In the literature data, there are many works investigating the addition of promoters $[30,32,39,40]$ and the influence of the preparation method [41-43] on catalytic properties of copper supported catalysts. Despite the high activity and selectivity of copper catalysts in the methanol conversion reaction, research is still ongoing to improve their catalytic properties in the investigated process [6]. Therefore, many research centers are trying to understand the mechanism and kinetics of individual methanol processing reactions [44-52]. The mechanism of methanol processing reactions has been studied in the literature data by various scientists, but $\mathrm{H}_{2}$ production from methanol is an issue still raised in many works. Various mechanisms of methanol reforming processes have been proposed in the literature, depending on the role of various active centers present on the copper 
catalyst surface, such as $\mathrm{Cu}^{0}$ [53], $\mathrm{Cu}^{+}[54]$ or $\mathrm{Cu}^{0}-\mathrm{Cu}^{+}$[49] couples. The methanol adsorption and decomposition measurements performed on $\mathrm{Cu} 100$ and $\mathrm{Cu} 110$ surfaces showed that methanol dissociates from methoxy species $\left(\mathrm{CH}_{3} \mathrm{O}\right)$. The recent studies proved that the presence of absorbed $\mathrm{O}$ on the copper surface enhances the formation of methoxy species [49]. Other authors also reported that methanol interacted very weakly on clean $\mathrm{Cu}(100)$ [55], $\mathrm{Cu}(110)$ [56], and $\mathrm{Cu}(111)$ [57] surface, what confirmed the need for activation of the catalysts by partial exposure of the catalyst surface by $\mathrm{O}_{2}$. Wachs et al. [56] reported that the dissociative chemisorption of $\mathrm{CH}_{3} \mathrm{O}-\mathrm{H}$ on $\mathrm{Cu}$ increased by the specific interaction, which takes place between the hydroxyl end of the methanol molecule and surface oxygen atoms (see Table 3). Moreover, the $\mathrm{Cu}^{\delta+} \mathrm{O}^{\delta-}$ site facilitates the breakdown of the $\mathrm{O}-\mathrm{H}$ bond present in the methanol molecule. The surface oxygen comes from the incomplete reduction of the catalyst or reaction atmosphere formed near the space of the catalyst bed during the reaction. In addition, Fisher et al. [56] reported about the dissociation of water to $\mathrm{H}_{2}$ and $\mathrm{O}$ even at $73{ }^{\circ} \mathrm{C}$ on reduced polycrystalline $\mathrm{Cu}$ [58]. The reaction scheme of POM, SRM and OSRM reactions is complicated by a few secondary reactions which run in parallel to the methanol dehydrogenation process. These reactions are listed below:

Total oxidation of methanol (TOM)

$$
\mathrm{CH}_{3} \mathrm{OH}+3 / 2 \mathrm{O}_{2} \rightarrow 2 \mathrm{CO}_{2}+2 \mathrm{H}_{2}
$$

Water-gas shift reaction (WGS)

$$
\mathrm{CO}+\mathrm{H}_{2} \mathrm{O} \rightleftarrows \mathrm{H}_{2}+\mathrm{CO}_{2}
$$

PROX reaction

$$
\mathrm{CO}+1 / 2 \mathrm{O}_{2} \rightleftarrows \mathrm{CO}_{2}
$$

Oxidation of $\mathrm{H}_{2}$

$$
\mathrm{H}_{2}+1 / 2 \mathrm{O}_{2} \rightleftarrows \mathrm{H}_{2} \mathrm{O}
$$

Taking into consideration the above processes, it could be emphasized that $\mathrm{CO}$ could be produced or reacted within all presented above reactions. That is why the concentration of carbon monoxide should be carefully controlled, taking into account the further use of reforming of methanol reactions for the production of hydrogen for fuel cells. It should be remembered that $\mathrm{CO}$ is a serious poison of platinum electrodes used in fuel cell technology. It is well known that even trace amounts of carbon monoxide can chemisorb irreversibly on the surface of the platinum electrodes, stopping the operation of the fuel cell. Methanol decomposition has been regarded as the easiest process of $\mathrm{H}_{2}$ production from methanol, and it runs during other methanol-reforming processes, including SRM, OSRM and POM. Up to date, there are four reaction possible schemes proposed for SRM reaction. Namely, MD-WGSR scheme, 1-step SRM scheme, SRM-MD-reverse-WGSR scheme and methyl formate scheme [59] (see Table 3). According to the MD-WGSR reaction scheme, CO is the primary product of the reaction, which is produced from the methanol dehydrogenation process. Then in the next step, $\mathrm{CO}$ subsequently is converted into $\mathrm{CO}_{2}$ via water gas shift (WGS) reaction [60]. Within the 1-step of the SRM reaction, $\mathrm{CO}_{2}$ and $\mathrm{H}_{2}$ are formed directly from the methanol dehydrogenation process [24]. This 1-step SRM scheme may be complicated in the case of the reaction carried out with high methanol conversion and contact time where $\mathrm{CO}$ started to be formed. Breen et al. [61] investigated the $\mathrm{Cu} / \mathrm{ZnO} / \mathrm{Al}_{2} \mathrm{O}_{3}$ catalysts promoted by $\mathrm{ZrO}_{2}$ and reported that the conversion of methanol was completed at about $345^{\circ} \mathrm{C}$ and $\mathrm{CO}$ has formed starts from $300{ }^{\circ} \mathrm{C}$, even though its formation is thermodynamically permitted at a lower temperature. In addition, the concentration of $\mathrm{CO}$ increase with increase of the reaction temperature and is not formed at low contact time. The reaction conditions of the process are presented in Table 3. Agrell et al. [62] reported that the low CO concentration is connected with the fact that CO is formed during the reverse-WGSR process, which runs during the reforming process. The authors also have experimentally confirmed that the quantity of $\mathrm{CO}$ formed during the process was decreasing with reducing contact time. This result indicates that a short contact 
time decreases the quantity of CO produced from the reverse-WGSR reaction. Peppley et al. [45] also investigated the SRM reaction and claimed that MD-WGSR and 1-step SRM schemes did not describe the mechanism of this reaction. Based on their results, they reported that all the MD, WGSR and SRM steps must be included in the mechanism model of the investigated reaction. The authors claimed that during SRM, MD process run parallel as a side reaction. The products of steam-reforming of methanol process are consumed via reverse-WGSR process (see Table 3 ). The kinetic model suggested by the authors [63-65] confirmed that two different centers present on the catalyst surface were required. One kind of the active centers are required for both the SRM and reverse WGSR processes (see Table 3). The second kinds of the active centers are required for the methanol decomposition reaction. On the other hand, a methyl formate scheme of steam-reforming of methanol has been also proposed by several scientists [66-68] (see Table 3). According to this scheme at first step methanol is dehydrogenate to methyl formate and then, the methyl formate is hydrolyzed into formic acid. In the next stage of the process the formic acid decompose to $\mathrm{CO}_{2}$ and $\mathrm{H}_{2}$ which were the primary products of the system. All of the steam-reforming of methanol reaction stages remaining above are presented in Figure 4.

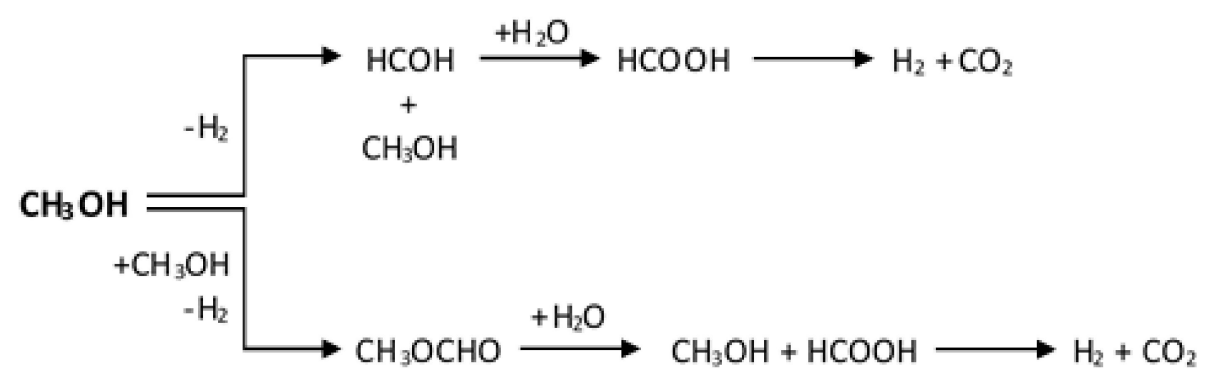

Figure 4. The reaction steps taking place during the steam-reforming of methanol process [69].

Authors based on their results reported that methanol dehydrogenation reaction is the rate-determining step of the SRM process. However, the MD-WGSR scheme could be ruled out because the concentration of $\mathrm{CO}$ in the product mixture was below the predicted value resulting from the equilibrium of the SRM process. The produced CO via SRM reaction is a primary product, which was produced by the decomposition of methyl formate according to the reaction below:

$$
\mathrm{HCOOCH}_{3} \rightarrow \mathrm{CH}_{3} \mathrm{OH}+\mathrm{CO}
$$

Partial oxidation of methanol reaction carried out using molar ratios of $\mathrm{O}_{2} / \mathrm{CH}_{3} \mathrm{OH}$ equal 0.3 and 0.4 were tested by Murcia-Mascaros et al. [70] (see Table 3). The catalytic activity results obtained by the authors indicated that both methanol conversion and concentrations of products strongly depend on the $\mathrm{O}_{2}$ concentration in the reaction mixture. During the partial oxidation of methanol, a significant amount of water and $\mathrm{CO}_{2}$ together with a small amount of $\mathrm{H}_{2}$ was observed at low methanol conversion and in the case of the reaction during which $\mathrm{O}_{2}$ was not completely consumed. Therefore, TOM and MD processes were proposed to be the dominating reactions at the initial stage of the partial oxidation of methanol. In contrast, when oxygen in the reaction mixture is almost consumed, the conversion of methanol increased to a value higher than that resulting from the reaction stoichiometry. At the same time, selectivity towards $\mathrm{H}_{2}$ production increases and towards $\mathrm{CO}$ formation decreases. Based on the obtained results, the authors reported that during the TOM process, a parallel SRM reaction takes place. Agrell et al. [11] also proposed a scheme of TOM-SRM consecutive pathway reactions for the partial oxidation of methanol reaction. Rabe and Vogel [71] also investigated POM reaction on $\mathrm{Cu} / \mathrm{ZnO} / \mathrm{Al}_{2} \mathrm{O}_{3}$ catalyst using thermogravimetric analysis coupled with Fourier-transform infrared (FTIR) spectroscopy (see Table 3). The authors reported that the POM reaction from an oxygen-poor mixture leads to the formation of formaldehyde and water. The results also confirmed that $\mathrm{CO}_{2}$ was produced as a primary product of the POM reaction. According to the literature [11], the OSRM reaction is very similar to the partial oxidation of the methanol reaction scheme, in which 
TOM runs successively through the SRM. The reaction scheme ends with a partial CO oxidation or RWGS reaction. The hydrogen and water production via the OSRM process is related to the relation between copper species and the TOM-SRM consecutive reaction scheme. During the TOM reaction, the metallic copper surface of the pre-reduced $\mathrm{Cu} / \mathrm{ZnO} / \mathrm{Al}_{2} \mathrm{O}_{3}$ catalyst was completely oxidized into $\mathrm{Cu}^{2+}$ by the oxygen present in the reaction mixture. At the point at which oxygen is consumed in the subsequent reaction SRM, the reaction mixture may again become a reduction. As a result, $\mathrm{Cu}^{2+}$ can be converted back into metallic copper. In addition, the copper species play different roles during OSRM depending on the degree of oxidation of $\mathrm{Cu}$. $\mathrm{Cu}^{2+}$ species show negligible activity in $\mathrm{H}_{2}$ production. These centers are active in the formation of water and carbon dioxide. Whereas, metallic copper are very active for the $\mathrm{H}_{2}$ production. The above proposed mechanism is compatible with the results reported by Reitz et al. [53]. They studied the OSRM reaction using $\mathrm{Cu} / \mathrm{ZnO}$ catalyst by X-ray absorption near edge structure (XANES) technique. The results showed that at low methanol conversion value, $\mathrm{Cu}^{2+}$ was the dominant $\mathrm{Cu}$ species, and combustion was the main reaction. In the case of the total conversion of $\mathrm{O}_{2}, \mathrm{Cu}^{2+}$ species were reduced to $\mathrm{Cu}^{0}$, and as a consequence, $\mathrm{H}_{2}$ is produced via the SRM process. Agrell et al. [11] reported that the gaseous products formed in POM and OSRM reactions and methanol conversions value were very similar. At the same time, during the SRM reaction, both the methanol conversion and $\mathrm{H}_{2}$ production were initiated at a lower reaction temperature on the metallic copper surface. Whereas, during POM and OSRM reactions the methanol conversion and $\mathrm{H}_{2}$ production were slower at a higher reaction temperature. The lower catalytic activity of both POM and OSRM reactions should be related to TOM process occurred on the $\mathrm{Cu}^{2+}$ species. Whereas, the higher catalytic efficiency is attributed to the SRM reaction that takes place on the metallic copper surface. On the other hand, Patel and Pant [72] proposed a different reaction scheme for OSRM reaction. The conditions of the OSRM process are given in Table 3. Authors reported that during OSRM reaction, partial oxidation of methanol, steam-reforming of methanol and RWGS processes run parallel. A kinetic model for the OSRM system over $\mathrm{Cu} / \mathrm{ZnO} / \mathrm{CeO}_{2} / \mathrm{Al}_{2} \mathrm{O}_{3}$ catalyst was developed by using Langmuir-Hinshelwood mechanism. The authors based on their results proposed that TOM was impossible due to the low molar ratio of $\mathrm{O}_{2}$ to $\mathrm{CH}_{3} \mathrm{OH}$ in a reaction mixture together with the excess of steam introduced in a reaction mixture used during the oxy-steam of methanol reaction. The scientists claimed that there are two different types of active sites on the catalyst surface. First kind of the active centers are used for the adsorption of $\mathrm{C}$ - and O-containing species. While, the second types of the active centers present on the catalyst surface are designed for the adsorption of $\mathrm{H}$. According to the previous work describing in the literature data [73-75] (see Table 3), CO is formed as a secondary product from the consecutive RWGS process. The kinetic model proposed by the authors is based on the assumption that formate is formed from oxymethylene in the process of partial oxidation of methanol, which determines the reaction rate determining step (RDS). In this model steam-reforming of methanol run through the dissociation of formic acid, from which adsorbed carbon monoxide and hydroxyl groups are formed. The predicted mechanism was also proved by the experimental data obtained by the authors in the OSRM process. Turco et al. [49] also determined the kinetic parameters based on the methanol conversion values in order to understand the differences in the activity of the investigated catalytic systems (see Table 3). They calculated the kinetic constant $\mathrm{k}$ $\left(\mathrm{s}^{-1} \mathrm{~cm}^{3}\right.$ gcat $\left.^{-1}\right)$ from the equation presented below and assumed for OSRM reaction that fractional expansion $\varepsilon=0.32$.

$$
k=\frac{1}{\tau}[\varepsilon x+(1+\varepsilon) \ln (1-x)]
$$

where, $\tau$ - contact time $\left(\mathrm{s} \cdot \mathrm{cm}^{-3} \cdot \mathrm{g}_{\text {cat }}\right)$ and $x$-fractional conversion;

Kinetic studies for the OSRM process based on copper catalysts have been conducted. Moreover, the Arrhenius plots presented by the authors show a satisfactory linear regression. Table 2 presents the activation energy values (Ea) obtained for the investigated catalysts. It was also observed that the $k$ values for the OSRM process are not correlated with the copper area. This result is a consequence of the complexity of the OSRM reaction. During the OSRM process, the POM reaction takes place, 
which is catalyzed by copper oxide in the first zone of the catalyst bed with access to high oxygen concentration. They reported that the interaction with other oxides could influence the activity of such $\mathrm{Cu}$ oxide, which may have an effect on the kinetics of POM reaction.

Table 2. Activation energy for the oxy-steam-reforming of methanol process [49].

\begin{tabular}{cc}
\hline Catalyst & $\mathbf{E}_{\mathbf{a}}$ (cal mol $^{\mathbf{- 1}}$ ) \\
\hline $\mathrm{Cu}(5) \mathrm{Zn}(50) \mathrm{Al}(45)$ & 24 \\
$\mathrm{Cu}(15) \mathrm{Zn}(48) \mathrm{Al}(37)$ & 27 \\
$\mathrm{Cu}(18) \mathrm{Zn}(33) \mathrm{Al}(49)$ & 16 \\
$\mathrm{Cu}(45) \mathrm{Zn}(31) \mathrm{Al}(24)$ & 22 \\
$\mathrm{Cu}(75) \mathrm{Zn}(25) \mathrm{Al}(0)$ & - \\
\hline
\end{tabular}

Turco et al. [48] also investigated the OSRM mechanism on $\mathrm{Cu} / \mathrm{ZnO} / \mathrm{Al}_{2} \mathrm{O}_{3}$ by FTIR technique, and they reported in their work that methanol adsorbs dissociatively on the catalyst surface (see Table 3). Methoxy groups are adsorbed both on the active sites and on inert regions of the catalyst surface, mainly associated with alumina. Methoxy groups in the vicinity of copper or adsorbed directly on it are easily transformed into surface forms of the formate. Based on their research, the authors discovered traces of formaldehyde also adsorbed on the catalyst surface. In the next step, the formate groups decompose to $\mathrm{CO}$ at or above $300^{\circ} \mathrm{C}$. The FTIR measurements also confirmed the formation of dimethyl ether during the OSRM process. Base on the above discussion, the authors proposed the following reaction scheme of the OSRM process carried out on the copper catalyst supported on $\mathrm{ZnO} \cdot \mathrm{Al}_{2} \mathrm{O}_{3}$ carrier (see Figure 5).

A - SRM, B - MD, C - DME formation, D - POM, E - RWGS, F - WGS

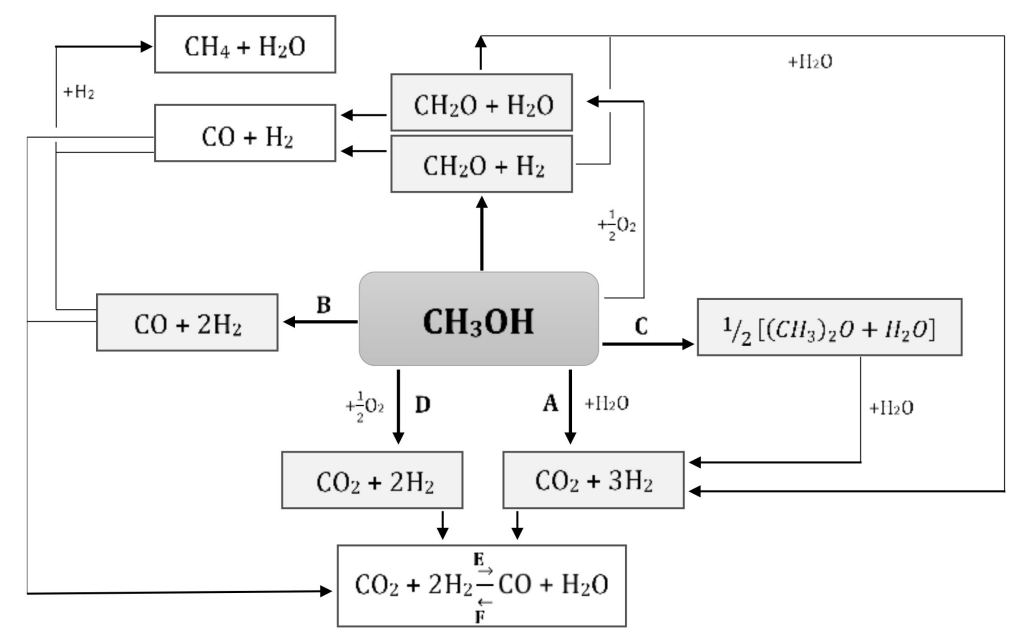

Figure 5. The reaction network taking place during oxidative steam-reforming of methanol (OSRM) process [48].

The authors reported in their work that the mechanisms of MD (reaction B), POM (reaction D), and SRM (reaction A) reactions are closely related and that the surface phenomena are similar. They also observed that the conversion of methanol in the presence of both water (SRM) and oxygen (POM) is higher compared to the methanol decomposition reaction what is directly related to the oxidation state of $\mathrm{Cu}$ present on the catalyst surface. It should also be emphasized that a small amount of carbon monoxide is formed in the presence of water (SRM), and $\mathrm{CO}_{2}$ is the dominant product. The FTIR results clearly showed that $\mathrm{CO}$ and $\mathrm{CO}_{2}$ are formed in appreciable amounts in the POM reaction. It is also known that $\mathrm{CO}$ is adsorbed very weakly on metallic copper particles [52], while it is adsorbed very strongly on $\mathrm{Cu}(\mathrm{I})$ centers. $\mathrm{CO}$ is easily oxidized to $\mathrm{CO}_{2}$ on $\mathrm{Cu}$ (II) centers. During the methanol 
decomposition reaction, the catalyst is completely reduced, and in this case, $\mathrm{CO}$ is produced by the decomposition of the formate groups. In contrast, the catalyst is partially oxidized during the POM reaction. Therefore, the $\mathrm{Cu}(\mathrm{I})$ sites present on the catalyst surface may strongly adsorb $\mathrm{CO}$, while $\mathrm{Cu}(\mathrm{II})$ allows its oxidation to $\mathrm{CO}_{2}$ before its desorption. Based on this assumption, $\mathrm{CO}_{2}$ is the main product of the POM process. During the POM reaction, when $\mathrm{O}_{2}$ is consumed, the excess methanol partially decomposes to CO. However, in the case of the SRM reaction, $\mathrm{CO}$ is formed in a limited amount. It can also be assumed that the water vapor present during the SRM process oxidizes the catalyst surface, leading to the formation of $\mathrm{Cu}$ (II) centers on which $\mathrm{CO}_{2}$ is formed. The authors also report that the scheme of the methanol decomposition mechanism was reasonably proposed by Riva et al. [76] (see Figure 6).

Table 3. Reaction conditions and catalytic materials applied in the studied process.

\begin{tabular}{|c|c|c|c|c|c|c|c|}
\hline \multirow[b]{2}{*}{ References } & \multirow[b]{2}{*}{$\begin{array}{l}\text { Investigated } \\
\text { Mechanism }\end{array}$} & \multirow[b]{2}{*}{$\begin{array}{l}\text { Employed } \\
\text { Catalyst }\end{array}$} & \multicolumn{5}{|c|}{ Operating Conditions } \\
\hline & & & $\begin{array}{l}\text { Total Flow } \\
{\left[\mathrm{cm}^{3} / \mathrm{min}\right]}\end{array}$ & $\begin{array}{c}\text { Temperature } \\
{[\mathrm{K}]}\end{array}$ & $\begin{array}{c}\text { Pressure } \\
\text { [atm] }\end{array}$ & $\mathrm{H}_{2} \mathrm{O} / \mathrm{CH}_{3} \mathrm{OH}$ & $\mathrm{O}_{2} / \mathrm{CH}_{3} \mathrm{OH}$ \\
\hline [56] & $\begin{array}{l}\text { Selective oxidation } \\
\text { of } \mathrm{CH}_{3} \mathrm{OH} \text { to } \mathrm{H}_{2} \mathrm{CO}\end{array}$ & Copper (110) & - & 295 & - & - & - \\
\hline [59] & SRM & Copper containing catalyst & - & $360-573$ & 1 & 1.5 & - \\
\hline [60] & SRM & $\mathrm{Cu} / \mathrm{ZnO} / \mathrm{Al}_{2} \mathrm{O}_{3}$ & - & $433-473$ & 1 & - & - \\
\hline [61] & SRM & $\mathrm{CuO} / \mathrm{ZnO} / \mathrm{ZrO}_{2} / \mathrm{Al}_{2} \mathrm{O}_{3}$ & - & 473 and 573 & 1 & 1.3 & - \\
\hline [62] & SRM & $\mathrm{Cu} / \mathrm{ZnO} / \mathrm{Al}_{2} \mathrm{O}_{3}$ & 230 & $448-623$ & 1 & 1.3 & - \\
\hline [77] & SRM & $\mathrm{Cu} / \mathrm{ZnO} / \mathrm{Al}_{2} \mathrm{O}_{3}$ & 50 & $433-533$ & $1-35$ & $0-1.2$ & - \\
\hline [45] & SRM & $\mathrm{Cu} / \mathrm{ZnO} / \mathrm{Al}_{2} \mathrm{O}_{3}$ & 50 & $433-533$ & $1-35$ & $0-1.2$ & - \\
\hline [63] & SRM & $\mathrm{Cu} / \mathrm{ZrO}_{2} / \mathrm{CeO}_{2}$ & - & 523 & 1 & 1.0 & - \\
\hline [66] & SRM & $\mathrm{Cu} / \mathrm{ZnO} / \mathrm{Al}_{2} \mathrm{O}_{3}$ & - & $443-533$ & 1 & - & - \\
\hline [67] & SRM & $\mathrm{Cu} / \mathrm{Zn} / \mathrm{Zr} / \mathrm{Al}$ & 38.6 & $413-618$ & 1 & 1.3 & - \\
\hline [47] & SRM & copper-silica & - & 433 and 453 & 1 & - & - \\
\hline [69] & SRM & copper-silica aerogel & - & $423-673$ & 1 & 2.0 & - \\
\hline [70] & OSRM & $\mathrm{Cu} / \mathrm{ZnO} / \mathrm{Al}_{2} \mathrm{O}_{3}$ & 120 & $473-633$ & 1 & 1.1 & 0.3 \\
\hline [71] & $\mathrm{POM}$ & $\mathrm{Cu} / \mathrm{ZnO} / \mathrm{Al}_{2} \mathrm{O}_{3}$ & - & 453 and 493 & - & - & $0.1-0.5$ \\
\hline [72] & OSRM & $\mathrm{Cu} / \mathrm{ZrO}_{2} / \mathrm{CeO}_{2} / \mathrm{Al}_{2} \mathrm{O}_{3}$ & - & $473-573$ & 1 & 1.5 & $0.1-0.2$ \\
\hline [73] & OSRM & $\mathrm{Cu} / \mathrm{CeO}_{2} / \mathrm{Al}_{2} \mathrm{O}_{3}$ & - & $473-573$ & 1 & 1.5 & $0-0.5$ \\
\hline [74] & OSRM & $\begin{array}{c}\mathrm{Cu} / \mathrm{ZnO} / \mathrm{Al}_{2} \mathrm{O}_{3} \\
\mathrm{Cu} / \mathrm{ZnO} / \mathrm{Al}_{2} \mathrm{O}_{3} / \mathrm{Cr}_{2} \mathrm{O}_{3}\end{array}$ & 100 & $538-548$ & 1.28 & 1 & 0.9 \\
\hline [48] & OSRM & $\mathrm{Cu} / \mathrm{ZnO} / \mathrm{Al}_{2} \mathrm{O}_{3}$ & - & $473-673$ & - & 1.1 & 0.12 \\
\hline
\end{tabular}

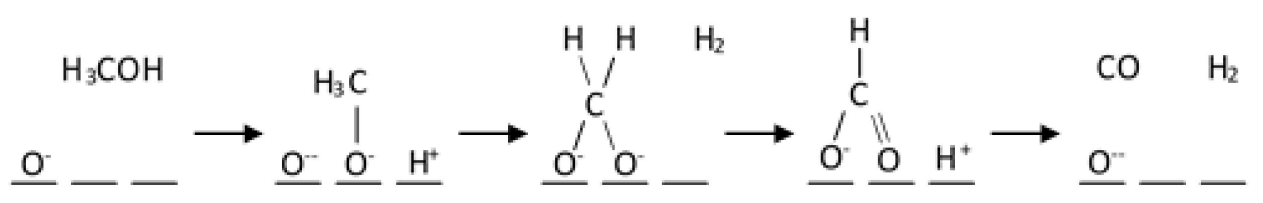

Figure 6. The methanol decomposition (MD) mechanism [60].

\section{Catalysts Configuration Systems Applied for Hydrogen Production in the Oxy-Steam Reforming of Methanol Process}

A literature review concerning catalysts systems applying in reforming of methanol processes indicates that the typical catalysts are $\mathrm{Cu}, \mathrm{Ni}, \mathrm{Co}, \mathrm{Fe}, \mathrm{Pd}, \mathrm{Pt}, \mathrm{Ru}, \mathrm{Au}, \mathrm{Ir}, \mathrm{Ag}$ supported on mono- $\mathrm{Al}_{2} \mathrm{O}_{3}$, $\mathrm{ZnO}, \mathrm{CeO}_{2}, \mathrm{MgO}, \mathrm{La}_{2} \mathrm{O}_{3}, \mathrm{SiO}_{2}[21,73,78,79]$, and binary oxides: $\mathrm{ZnO}-\mathrm{Al}_{2} \mathrm{O}_{3}, \mathrm{CeO}_{2}-\mathrm{ZrO}_{2} . \mathrm{SiO}_{2}-\mathrm{SnO}_{2}$, $\mathrm{A}_{2} \mathrm{O}_{3}-\mathrm{CeO}_{2}[32,73,79,80]$. Those catalytic systems are prepared using different methods including: microemulsion [81], aerogel [82], co-precipitation [43], sol-gel [83], impregnation [46], combustion synthesis [84], and others. However, still, the most common catalysts used for oxy-steam reforming of methanol reaction are the copper-based systems. Their metal surface area is determined by the chemisorption method; high values of copper dispersion are the targets to attain for the achievement of highly active catalysts. In the literature data, there are many works investigating the addition of 
promoters $[30,32,39,40]$ and the influence of the preparation method [41-43] on catalytic properties of copper supported catalysts. Despite the high activity and selectivity of copper catalysts in the methanol conversion reaction, research is still ongoing to improve their catalytic properties in the investigated process [6].

4.1. The Influence of the Preparation Method on the Catalytic Properties of the Tested Catalytic Systems in the Oxy-Steam Reforming of Methanol Process

The effect of the preparation method of copper catalysts on their catalytic properties in the oxidative steam-reforming of methanol was studied by Shen and Song [42]. They have compared the physicochemical properties of copper catalysts synthesized by impregnation, co-precipitation and hydrothermal synthesis methods, and they claimed that the systems prepared using the co-precipitation method exhibited higher surface area ( $46 \%$ higher than wet impregnation) and methanol conversion in the oxidative steam-reforming of methanol reaction. The activation of the catalyst through the reduction process performed before each catalyst test at lower temperature results in increasing the activity towards hydrogen production. The $\mathrm{CuO} / \mathrm{ZnO} / \mathrm{Al}_{2} \mathrm{O}_{3}$ catalyst prepared by the co-impregnation method was also examined in the oxidative steam-reforming of the methanol process. The lowest $\mathrm{CO}$ concentration close to zero was observed when $\mathrm{H}_{2} \mathrm{O} /$ methanol and $\mathrm{O}_{2} /$ methanol ratio equal to 1.43 and 0.47, respectively. Papavasiliou et al. [39] investigated $\mathrm{Cu}-\mathrm{Mn}$ spinel oxide catalysts as an alternative to a commercial $\mathrm{CuO} / \mathrm{ZnO} / \mathrm{Al}_{2} \mathrm{O}_{3}$ catalyst. The physicochemical properties and catalytic characterization of the investigated catalysts applied in OSR of methanol reaction are given in Table 4. The $\mathrm{Cu}_{\mathrm{x}}-\mathrm{Mn}_{\mathrm{y}}$ catalytic systems were synthesized by the urea nitrate combustion method. The activity results showed that the investigated catalysts exhibited high activity to $\mathrm{H}_{2}$ production in combined (oxy-steam) reforming of methanol reaction. The most active catalysts which exhibited almost identical activity and selectivity results were $\mathrm{Cu}_{0.30}-\mathrm{Mn}_{0.70}$ and $\mathrm{Cu}_{0.40}-\mathrm{Mn}_{0.60}$ catalysts. Their high activity in the studied reaction is explained by their almost identical physicochemical properties which were confirmed by XRD and XPS analysis. The authors also investigated the stability of $\mathrm{Cu}_{0.30}-\mathrm{Mn}_{0.70}$ and commercial $\mathrm{CuO} / \mathrm{ZnO} / \mathrm{Al}_{2} \mathrm{O}_{3}$ catalysts in combined (oxy-steam) reforming of methanol reaction at $300{ }^{\circ} \mathrm{C}$ within $8 \mathrm{~h}$ of operation. The only observed difference between the tested systems was the value of the hydrogen selectivity, which was higher for the $\mathrm{Cu}_{0.30}-\mathrm{Mn}_{0.70}$ catalyst. Catalysts operated stably under the reaction conditions, demonstrating constant selectivity towards $\mathrm{H}_{2}$ formation and a slight decrease in methanol conversion from 99 to $96 \%$ after $8 \mathrm{~h}$ of catalyst operation. Other catalysts prepared by Papavasiliou et al. [79] were $\mathrm{CuO}-\mathrm{CeO}_{2}$ systems prepared by the urea-nitrate combustion method. The activity tests were performed in combined (oxy-steam (CRM) reforming of methanol) reaction. The result presented in Table 4 shows that the catalyst surface area and crystallites size could be controlled and optimized by the preparation method. The authors reported that the optimal fuel to oxidant ratio (urea/nitrates) was 4.17 and the optimal $\mathrm{Cu} /(\mathrm{Cu}+\mathrm{Ce})$ atomic ratio was 0.15 , with the surface area increasing by about 4.3 times, while the methanol conversion increased from $52 \%$ to $100 \%$, and the activity increased by about 1.8 times. The comparison of the activity in SRM and CRM showed that under autothermal conditions, the activity of the catalyst was improved. The higher methanol conversion obtained during the CRM process is assigned to better efficiency of the heat transferring in the catalyst bed. In CRM reaction, the methanol conversion obtained at $300^{\circ} \mathrm{C}$ was equal to $100 \%$ with more than $97 \%$ selectivity toward hydrogen formation. However, the $\mathrm{CO}$ concentration increased in all cases by increasing the reaction temperature. Liu et al. [85] studied $\mathrm{Pd} / \mathrm{ZnO}$ catalysts prepared by impregnation and co-precipitation methods and tested their catalytic activity in the oxidative steam-reforming of the methanol process (see Table 4). In addition, the authors also investigated the influence of Pd loading on the activity results in the tested reaction. The $\mathrm{Pd} / \mathrm{ZnO}$ catalysts with Pd loading below $5 \%$ prepared by impregnation method (IP method) showed better activity in the oxidative reforming of methanol process compared to samples prepared by co-precipitation (CP) method. This is due to the higher concentration of the PdZn alloy on the surface of the catalyst prepared by the IP method. Nevertheless, for the higher Pd loading, the $\mathrm{Pd} / \mathrm{ZnO}$ catalysts prepared 
by CP method were more active than system prepared by IP method. Based on the obtained results, the authors concluded that the activity of the catalyst strongly depends on the crystal size and the dispersion of the PdZn alloy on the $\mathrm{ZnO}$ support. Increasing the size of the Pd crystals on the $\mathrm{ZnO}$ support improves the catalytic activity and selectivity of the palladium catalysts. Moreover, the amount of $\mathrm{CO}$ generated during the tested process is effectively reduced, along with an increase in the Pd content in the catalytic material.

\subsection{Effect of the Type of Carrier on the Catalytic Reactivity of the Catalytic Systems Applied in the Oxy-Steam Reforming of Methanol}

The type of support and its nature has a great influence on the catalyst material activity and stability [86]. The promotion of copper catalyst by $\mathrm{CeO}_{2}$ leads to an increase of the thermal stability in steam-reforming of methanol reaction [78]. $\mathrm{CeO}_{2}$ itself can provide mobile oxygen, which has a direct influence on the catalytic activity and may affect the oxidation state of the metal present on the support surface under a reducing environment. Recently, an increase in interest has in the case of catalysts supported on $\mathrm{CeO}_{2}$ has been observed. The crystal structure of $\mathrm{CeO}_{2}$ is a cubic fluorite network for which it is possible to introduce other cations, such as $\mathrm{Si}^{4+}, \mathrm{Th}^{4+}, \mathrm{Zr}^{4+}, \mathrm{Y}^{3+}, \mathrm{La}^{3+}, \mathrm{Sc}^{3+}$, $\mathrm{Mg}^{2+}, \mathrm{Ca}^{2+}$ or $\mathrm{Cu}^{2+}$ to improve catalytic properties of $\mathrm{CeO}_{2}$ [87]. High mobility oxygen present in the $\mathrm{CeO}_{2}$ containing systems [88], the strong interaction of $\mathrm{CeO}_{2}$ with supported metal—strong metal-support interaction (SMSI) [89], all these features make these systems as promising catalytic materials. The role of promoters of copper supported catalysts is one of the main factors which was brought up in many publications. Promoters have been used to influence the status of copper and improve the activity of the catalyst. Promotion of copper catalyst by $\mathrm{CeO}_{2}$ improves activity and stability of the copper-supported catalyst and leads also to the improvement of copper dispersion on catalyst surface and in the same time protects copper crystallites against poisoning and has influence on greatest crystallites formation [90]. Mierczynski et al. [91] studied the influence of copper content in monometallic $x \mathrm{Cu}$ (where, $\mathrm{x}=5,20,40$ and $60 \mathrm{wt}$ \%) catalysts supported on binary oxide $\mathrm{CeO}_{2} \cdot \mathrm{Al}_{2} \mathrm{O}_{3}$ on the activity of these systems in the oxy-steam reforming of methanol reaction and the results are presented in Table 4 . The authors confirmed that the reactivity of the investigated systems depends on the copper content and its dispersion on the catalyst surface. These studies confirmed that the $20 \mathrm{wt}$. $\%$ of $\mathrm{Cu}$ content is the optimum content of copper in order to obtain the highest methanol conversion and reaction rate value compared to other investigated catalytic systems. In addition, the activation energy in the OSRM process for the $20 \% \mathrm{Cu} / \mathrm{CeO}_{2} \cdot \mathrm{Al}_{2} \mathrm{O}_{3}$ catalyst was the lowest and equal $66.56 \mathrm{~kJ} / \mathrm{mol}$. In other work [23], authors studied both mono-Ni and bimetallic Pd-Ni catalysts supported on $\mathrm{CeO}_{2}$, $\mathrm{Al}_{2} \mathrm{O}_{3}$ and $\mathrm{CeO}_{2} \cdot \mathrm{Al}_{2} \mathrm{O}_{3}$ carriers and they reported about the highest activity of bimetallic $2 \%$ Pd- $40 \%$ $\mathrm{Ni} / \mathrm{CeO}_{2} \cdot \mathrm{Al}_{2} \mathrm{O}_{3}$ system compared to the other investigated catalysts. This catalytic system showed the highest stability and selectivity to $\mathrm{H}_{2}$ production in the oxy-steam-reforming of methanol process compared to the systems supported on monoxide. In addition, they investigated the influence of the $\mathrm{Ni}$ loading on the catalytic activity of the prepared monometallic systems in the OSRM process. The results showed that system containing $40 \mathrm{wt}$.\% of Ni exhibited the highest methanol conversion value and the highest selectivity to hydrogen formation compared to the rest of the monometallic catalysts. Mierczynski et al. [18] extensively investigated the influence of support composition on the catalytic activity of copper catalysts in order to obtain optimal catalyst composition for the OSRM reaction (see the results presented in Table 4). They prepared various copper catalysts supported on binary oxides systems $\left(\mathrm{ZrO}_{2} \cdot \mathrm{Al}_{2} \mathrm{O}_{3}\right.$, where $\mathrm{Zr}: \mathrm{Al}=2: 1,1: 1$ and 1:2). The reactivity results performed in the oxy-steam-reforming of methanol confirmed that the highest active system was $20 \% \mathrm{Cu} / \mathrm{ZrO}_{2} \cdot \mathrm{Al}_{2} \mathrm{O}_{3}$ (1:2) catalyst. In further studies, the authors compared the physicochemical and catalytic properties of $\mathrm{Cu}$ catalyst with $\mathrm{Ni}$ system supported on $\mathrm{ZrO}_{2} \cdot \mathrm{Al}_{2} \mathrm{O}_{3}$ (1:2) carrier. The reactivity measurements showed that the supported copper catalyst was more active than the nickel catalyst. They have found that the catalytic activity of the investigated catalysts strongly dependent on their acidity and sorption properties in relation to methanol. The catalytic tests confirmed the highest activity of copper catalysts 
supported on $\mathrm{ZrO}_{2}-\mathrm{Al}_{2} \mathrm{O}_{3}(\mathrm{Zr}: \mathrm{Al}=0.5)$ binary oxide promoted by noble metals such as Pd or $\mathrm{Rh}$. The most active systems exhibited the highest specific surface area and the highest number of acidic centers on their surfaces. The XPS measurements showed that the catalyst with the lowest ratio between $\mathrm{Cu}^{0}$ and $\mathrm{Cu}^{+}$species present on the catalyst surface exhibited the highest activity in the OSRM process, and the relationship between these species is a critical parameter to achieve highly active systems in the OSRM reaction. Furthermore, they have found that the pre-treatment process of $\mathrm{Ni}$ catalysts carried out before the activity tests play a significant role in terms of the catalytic activity of the tested systems in the OSRM process. In other work [22], authors studied the influence of the binary oxide composition of $\mathrm{ZnO} \cdot \mathrm{Al}_{2} \mathrm{O}_{3}(\mathrm{Zn}: \mathrm{Al}=2: 1,1: 1,1: 2$ and 1:4) on the physicochemical and catalytic properties of nickel supported catalysts. The reactivity tests performed in the oxy-steam-reforming of methanol reaction showed that $20 \% \mathrm{Ni} / \mathrm{ZnO} \cdot \mathrm{Al}_{2} \mathrm{O}_{3}(1: 1)$ system was the most active catalysts in the investigated reaction at $300{ }^{\circ} \mathrm{C}$. This result was explained by the easiest reducibility, and the highest acidity of this catalyst compare to other investigated catalysts. Iwasa et al. investigated various metal catalysts $\mathrm{Me} / \mathrm{ZnO}$ (where $\mathrm{Me}=\mathrm{Fe}, \mathrm{Co}, \mathrm{Ni}, \mathrm{Pd}, \mathrm{Pt}$, Ir or $\mathrm{Ru}$ ) catalysts in transformation of methanol in the presence of steam and oxygen [92]. He proved that the best promising system was $\mathrm{Pd} / \mathrm{ZnO}$ monometallic catalyst. Their high activity was explained by intermetallic Pd-Zn formation. Similar to the $\mathrm{Pd} / \mathrm{ZnO}$ catalyst, the low selectivity of $\mathrm{Pt} / \mathrm{ZnO}$ towards $\mathrm{CO}$ was assigned to $\mathrm{PtZn}$ alloy formation. Whereas, in the case of $\mathrm{Ni}, \mathrm{Ru}, \mathrm{Co}$ and $\mathrm{Ir}$ catalyst, no alloy phase was formed after reducing the catalysts at $500{ }^{\circ} \mathrm{C}$. These catalysts showed low methanol conversion and produce a higher concentration of carbon monoxide [93,94]. Palladium is active component for methanol-reforming reactions. It is an effective decomposition catalyst, selectively forming $\mathrm{H}_{2}$ and $\mathrm{CO}$ when it is supported on metal oxide [95-98]. Udani et al. [99] also tested $\mathrm{Cu}-\mathrm{CeO}_{2}$ catalysts in the oxy-steam-reforming of methanol reaction. They investigated copper catalysts with various content of copper. They reported that catalyst with 70 at.\% Cu showed the highest catalytic activity in the studied process and was slightly better than commercial SRM catalyst (Synetix 33-5). In addition, the catalytic measurements performed in the OSRM process confirmed the stable operation of the catalytic system at $300{ }^{\circ} \mathrm{C}$. In the literature, data can be found only a few works concerning the use of carbon nanotubes as a carrier of catalytic system used in oxy-steam-reforming of methanol processes. The use of carbon nanotubes (CNTs) or multiwalled carbon nanotubes (MWCNTs) as a carrier for methanol-reforming catalysts is associated with the attractive properties of this material [100]. Carbon nanotubes were applied as a carrier of catalytic materials due to their specific structural morphology and their specific physicochemical properties. In addition, CNTs properties can be modified by functions groups introduced onto their surface. This modification possibilities gives capabilities to obtain specific material. Furthermore, catalysts supported on CNTs can be prepared by different methods such as: impregnation, precipitation, colloidal, electroless plating, and hydrothermal method [100]. The main advantage of carbon nanotubes used as a catalyst carrier is their high purity, high thermal and mechanical stability, the presence of specific interactions on the boundary metal-support, the possibility of adsorption of catalytically active nanoparticles inside or on the external wall of CNTs and their specific electron structure. Good conductivity of carbon nanotubes promotes the "spillover" effect in a place of interfacial boundary created by the active center [101]. Nanoparticles of an active phase dispersed on the functional surface of the support (CNTs) make that created active centers are easily accessible to the reactants. All remaining above properties of CNTs can directly affect the catalytic activity and selectivity [102-106]. All mentioned properties of CNTs material have an important influence on the catalytic activity and selectivity of the synthesized catalysts. Mierczynski et al. [19] reported the potential usages of MWCNTs in the OSRM reaction to hydrogen generation. They have confirmed that magnetite, metallic iron and defects formed by encapsulated or removal of metal particles play an important role in the oxy-steam-reforming of methanol. Their results indicate that MWCNTs are potential carriers for various metallic catalysts which can be applied in methanol processing reactions. 
4.3. Role of Promotors Addition on the Catalytic and Physicochemical Properties of Catalytic Materials Tested in the Oxy-Steam Reforming of Methanol Reaction

The role of promoters of copper supported catalysts is one of the main factors which was brought up in many publications. Promoters have been used to influence the status of copper and improve the activity of the catalyst. Modification of copper catalyst by $\mathrm{CeO}_{2}$ improves activity, the addition of $\mathrm{ZnO}$ and $\mathrm{ZrO}_{2}$ cause increase of catalyst surface, and also stabilize crystallites size of copper, and in the same time protects crystallites against their aggregations. Additionally, $\mathrm{ZrO}_{2}$ stabilizes the copper $\mathrm{Cu}^{+}$ions on the catalyst surface [39]. Agrell et al. [107] determined the influence of $\mathrm{ZrO}_{2}$ and $\mathrm{Al}_{2} \mathrm{O}_{3}$ promotion on physicochemical and catalytic properties of $\mathrm{Cu} / \mathrm{ZnO}$ catalyst (see the results presented in Table 4). The authors observed an increase in copper dispersion after adding $\mathrm{ZrO}_{2}$ to $\mathrm{Cu} / \mathrm{ZnO}$ catalyst. While the structural promoter $\mathrm{Al}_{2} \mathrm{O}_{3}$ provides a larger surface into catalytic systems, which directly leads to high dispersion of copper [30,107]. The authors observed an increase in both the total surface area and the degree of copper dispersion after the introduction of $\mathrm{Al}_{2} \mathrm{O}_{3}$ into the catalytic system. They also performed the activity tests of catalytic systems in the steam, partial oxidation and oxy-steam reforming of methanol processes. They reported that $\mathrm{ZrO}_{2}$ containing catalysts were more active compared to other investigated catalysts. $\mathrm{Cu} / \mathrm{ZnO} / \mathrm{ZrO}_{2}$ and $\mathrm{Cu} / \mathrm{ZnO} / \mathrm{ZrO}_{2} / \mathrm{Al}_{2} \mathrm{O}_{3}$ catalysts exhibited high activity in oxy-steam-reforming of methanol. It should be emphasized that the $\mathrm{Cu} / \mathrm{ZnO}$ catalyst was more efficient at low $\mathrm{CH}_{3} \mathrm{OH}$ conversion values. In the case of this system, the authors observed a lower amount of $\mathrm{CO}$ formed during the studied process compared to the amount of carbon monoxide generated during the steam-reforming reaction of methanol (SRM). As part of the work, the authors conducted stability studies in the process of oxy-steam reforming of methanol on $\mathrm{Cu} / \mathrm{ZnO}$ and $\mathrm{Cu} / \mathrm{ZnO} / \mathrm{ZrO}_{2} / \mathrm{Al}_{2} \mathrm{O}_{3}$ catalysts at a temperature of $260{ }^{\circ} \mathrm{C}$ within $20 \mathrm{~h}$ of operation. The results showed that $\mathrm{ZrO}_{2}$ addition improves the lifetime of the studied catalyst. A similar promotional effect attributed to $\mathrm{Cr}_{2} \mathrm{O}_{3} \mathrm{was}$ observed in other works $[40,108]$. The addition of this promotor acts as a stabilizer of the copper structure, protecting it against sintering. The promotion effect of palladium on the catalytic activity and selectivity towards hydrogen production of nickel-supported catalysts in the OSRM was studied by Mierczynski et al. [23]. The obtained results showed that the palladium addition facilitates the reducibility of the nickel supported catalysts. In addition, they confirmed the highest activity of Pd-Ni catalyst in the studied process, which exhibited the highest selectivity towards hydrogen production and towards carbon monoxide formation in the investigated reaction. Liu et al. [109] investigated the effects of modifier $(\mathrm{Zr}, \mathrm{Fe}, \mathrm{Mg}, \mathrm{Al}$ and $\mathrm{Cr}$ ) of a $\mathrm{Pd} / \mathrm{ZnO}$ catalyst prepared by co-precipitation method on the catalytic activity in the oxidative reforming of methanol reaction. The addition of modifier to $\mathrm{Pd} / \mathrm{ZnO}$ catalyst in the form of metal significantly modifies its physicochemical and catalytic properties in an oxidative reforming of methanol process. The $\mathrm{ZnO}$ crystal size decreases as a result of modifier addition. During high-temperature reduction treatment, the smaller PdZn alloy particles are formed. The introduced modifier can interact with $\mathrm{ZnO}$, which leads to the formation of binary oxides systems such as $\mathrm{ZnAl}_{2} \mathrm{O}_{4}, \mathrm{ZnCr}_{2} \mathrm{O}_{4}$ and $\mathrm{ZnFe}_{2} \mathrm{O}_{4}$. The promotion effect of a small amount of $\mathrm{Cr}$ or Fe into $\mathrm{Pd} / \mathrm{ZnO}$ catalyst results in decreases in the amount of $\mathrm{CO}$ formed during the process and increased the selectivity toward $\mathrm{H}_{2}$ production. However, the $\mathrm{CO}$ selectivity of the $\mathrm{Pd} / \mathrm{ZnO}$ catalyst increases as a result of $\mathrm{Mg}, \mathrm{Zr}$ or $\mathrm{Al}$ addition. Mierczynski et al. [18,22,23] also investigated the influence of Pd addition into Ni catalysts on their activity results in the OSRM process. The authors confirmed that the palladium addition has a promotion effect on the performance of Ni supported catalyst in the OSRM reaction. They proved that $\mathrm{Pd}$ facilitates the $\mathrm{NiO}$ reduction by the spillover effect occurring between $\mathrm{Pd}$ and $\mathrm{NiO}$ species. This phenomenon is related to the generation of new adsorption centers on the catalyst surface, which may be responsible for increasing the activity and selectivity of the bimetallic catalyst towards $\mathrm{H}_{2}$ formation. They also reported that the activity in the OSRM reaction strongly depends on the Ni content in the investigated system and their reduced properties. The acidity measurement also confirmed that acid sites play a crucial role in the oxy-steam-reforming of the methanol process. In addition, the presence of acid centers located close to high dispersed metal centers may have a significant influence on the reactivity of the tested catalyst systems. Catalytic activity 
tests performed for $48 \mathrm{~h}$ confirmed the stable operation of the Pd-Ni bimetallic catalyst. (see Figure 7). In another work [18], the authors also reported the high activity of bimetallic Rh-Cu, Rh-Ni and Pd-Cu, $\mathrm{Pd}-\mathrm{Ni}$ catalysts tested in the OSRM process. They confirmed that the most active system in the studied process was $0.5 \% \mathrm{Rh}-20 \% \mathrm{Cu} / \mathrm{ZrO}_{2} \cdot \mathrm{Al}_{2} \mathrm{O}_{3}(1: 2)$ catalyst (see Figure 8 ). They also claimed that the occurrence of $\mathrm{Cu}^{0}$ and $\mathrm{Cu}^{+}$species and their ratio is a critical parameter to achieve highly active systems in the OSRM reaction.

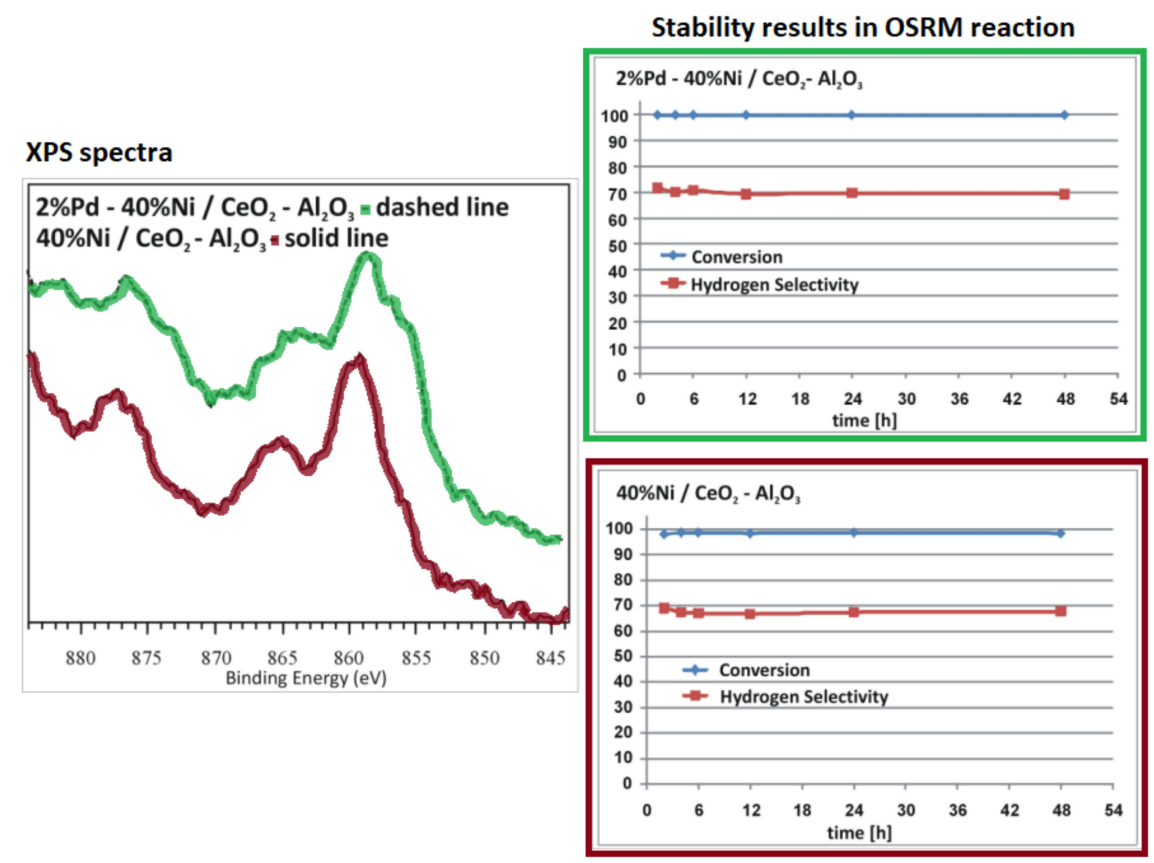

Figure 7. XPS and stability results during $48 \mathrm{~h}$ of the OSRM reaction performed at $250{ }^{\circ} \mathrm{C}$ after reduction $1 \mathrm{~h}$ at $300{ }^{\circ} \mathrm{C}[23]$.

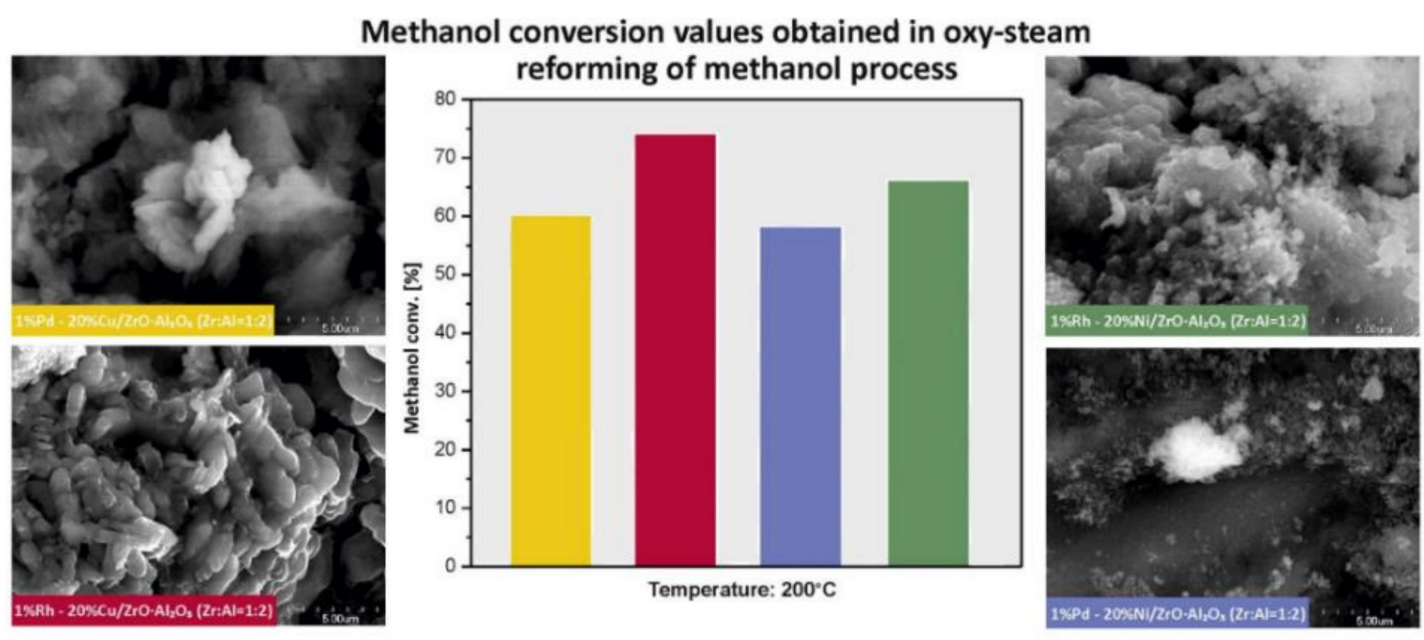

Figure 8. The activity results of $\mathrm{Rh}(\mathrm{Pd})-\mathrm{Cu}(\mathrm{Ni}) / \mathrm{ZrO}_{2} \cdot \mathrm{Al}_{2} \mathrm{O}_{3}(1: 2)$ catalysts in the OSRM process [18].

In other work [92], the authors reported the potential capability to use palladium as a promoter for methanol-reforming catalysts. Despite the relatively high price of gold, even a small addition of gold can significantly improves the activity of bimetallic catalysts through the formation of intermetallic compound $\mathrm{Au}-\mathrm{Cu}, \mathrm{Au}-\mathrm{Ni}$, which catalyze the OSRM process. Since Haruta's discovery that catalysts containing nanosized gold particles have extraordinary activities for reactions, including $\mathrm{CO}$ oxidation [110], there has been substantial interest in their use and the origin of their exceptional catalytic properties. The use of gold as a promoter of the active phase $(\mathrm{Cu}, \mathrm{Ni})$ results in lowering 
the reaction temperature and improves selectivity toward hydrogen and carbon dioxide formation. The selectivity improvement is associated with the surface modification of copper and nickel by gold atoms. These new atoms can generate new adsorption centers, which may be involved in the dissociative adsorption of methanol or adsorption of atomic oxygen as a result of dissociation of previously adsorbed methanol. Adsorbed oxygen atoms can leave the surface of the catalyst as a product of $\mathrm{CO}_{2}$, thereby reducing the formation of CO. Mierczynski et al. [17,111,112] for the first time investigated the physicochemical and catalytic activity of the mono- $(\mathrm{Cu}, \mathrm{Ni})$ and bimetallic $(\mathrm{Au}-\mathrm{Cu}$, $\mathrm{Au}-\mathrm{Ni}$ ) catalysts supported on multiwalled carbon nanotubes (MWCNTs) in oxy-steam-reforming of methanol process (see Figure 9). They proved that the $\mathrm{AuCu}$ and $\mathrm{AuNi}$ alloys are formed in the case of bimetallic $\mathrm{Au}-\mathrm{Cu} / \mathrm{MWCNTs}$ and $\mathrm{Au}-\mathrm{Ni} / \mathrm{MWCNTs}$ catalyst after their reduction. These results were confirmed by XRD, XPS and SEM-EDS measurements. The spillover effect between metallic gold and nickel (copper) oxide was confirmed by TPR- $\mathrm{H}_{2}$ studies. The bimetallic $\mathrm{Au}-\mathrm{Cu}$ catalyst exhibited a significant improvement of the activity and selectivity towards hydrogen formation compared to the monometallic systems tested in the OSRM process at higher temperatures $\left(300^{\circ} \mathrm{C}\right)$. The higher activity and selectivity towards $\mathrm{H}_{2}$ production is explained by an alloy $\mathrm{AuCu}$ formation. The Au-Ni/MWCNTs catalyst showed the lowest selectivity towards $\mathrm{CO}$ formation at 200 and $300^{\circ} \mathrm{C}$, which is very important from the application point of view of these catalytic systems in fuel cell technology.
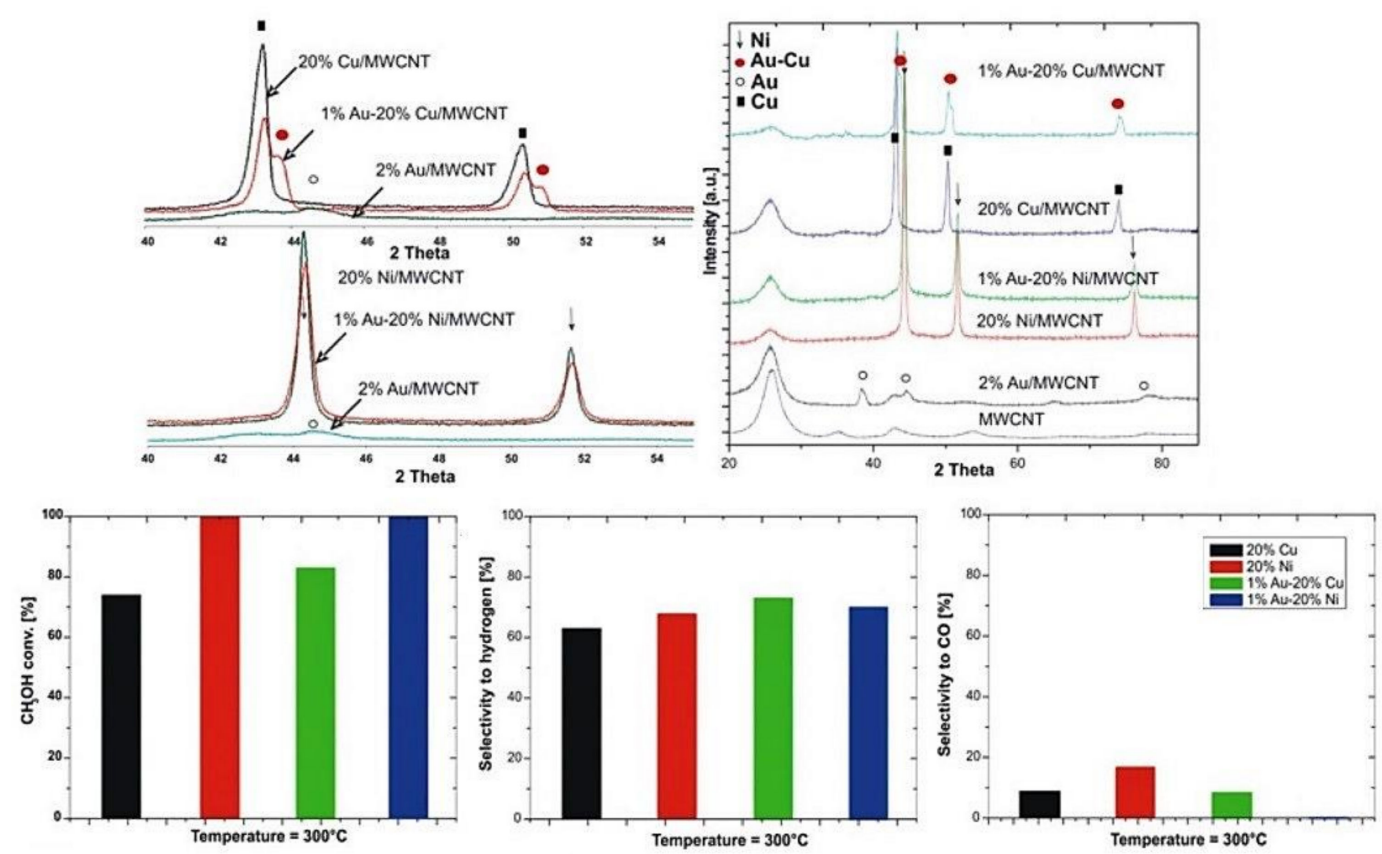

Figure 9. Phase composition studies of spent catalysts and reactivity results of bimetallic $\mathrm{Au}-\mathrm{Cu}$ and $\mathrm{Au}-\mathrm{Ni}$ system in the OSRM process [17].

4.4. Role of Active Phase Composition on Reactivity Properties of Catalytic Materials Applied in Oxy-Steam Reforming of Methanol

The type of an active phase has an important influence on the reactivity properties of synthesized catalysts in methanol processing reactions. It is well known that copper and nickel catalysts supported on metal oxide support are highly active in methanol processing reactions, as evidenced by a number of papers published in reputable journals concerning copper and nickel catalysts using in methanol reforming processes. In addition, transition metal catalysts and noble metals are also used in oxy-steam reforming of methanol reaction. The activity results obtained in steam-reforming of methanol reaction on $\mathrm{Pd} / \mathrm{ZnO}$ catalyst showed that palladium is an effective catalyst in the studied process. $\mathrm{Pd} / \mathrm{ZnO}$ system showed high selectivity for $\mathrm{CO}_{2}$ production in the SRM process. The high selectivity towards $\mathrm{CO}_{2}$ formation is explained by the Pd-Zn alloys formed on the catalyst surface [113]. These palladium 
alloys are formed at moderate temperatures under reducing conditions [114,115]. Iwasa et al. [92] also compared the catalytic properties of $\mathrm{Pd} / \mathrm{ZnO}$ catalyst with copper-containing systems $(\mathrm{Cu} / \mathrm{ZnO}$, $\mathrm{Cu} / \mathrm{ZrO}_{2}$ and $\left.\mathrm{Cu} / \mathrm{SiO}_{2}\right)$ in steam reforming of methanol reaction. The methanol conversion and hydrogen concentration obtained for $\mathrm{Pd} / \mathrm{ZnO}$ were higher compared to $\mathrm{Cu} / \mathrm{ZrO} \mathrm{O}_{2}$ and $\mathrm{Cu} / \mathrm{SiO}_{2}$ catalysts and slightly lower than for $\mathrm{Cu} / \mathrm{ZnO}$ system. The influence of $\mathrm{Pd}$ loading on $\mathrm{Pd} / \mathrm{ZnO}$ catalyst was examined, and obtained results showed the $\mathrm{CH}_{3} \mathrm{OH}$ conversion increased with increasing Pd loading. In the presence of oxygen, the distribution of reaction products depends on Pd loading. The increase od $\mathrm{Pd}$ concentration in $\mathrm{Pd} / \mathrm{ZnO}$ catalyst results in increasing of $\mathrm{H}_{2}$ and decreasing of $\mathrm{CO}$ level in an obtained reaction product. The $1 \% \mathrm{Pd} / \mathrm{ZnO}$ catalyst exhibited the highest concentration of $\mathrm{H}_{2} \mathrm{O}$ in the product in contrast to the $10 \% \mathrm{Pd} / \mathrm{ZnO}$ catalyst for which water was not a product of the reaction. $\mathrm{Xu}$ et al. [116] have been investigated Pt-based alloys, including Pt-Cr, Pt-Fe, Pt-Co, Pt-Ni and $\mathrm{Pt}-\mathrm{Au}$, as methanol-tolerant cathode catalysts. They reported that the $\mathrm{Pt}-\mathrm{Au}$ catalyst had been the most promising one in terms of both the catalytic activity and stability. Studies indicate that the methanol-tolerant mechanism of the Pt-based alloys can be attributed to the diluted Pt sites for methanol dehydrogenation as compared with the pure Pt catalyst.

Manzoli et al. [117] investigated $\mathrm{CuO} / \mathrm{ZnO}, \mathrm{Au} / \mathrm{ZnO}, \mathrm{Cu} / \mathrm{TiO}_{2}$ and $\mathrm{Au} / \mathrm{TiO}_{2}$ catalysts in the decomposition and oxy-steam reforming of methanol process. The catalyst systems supported on $\mathrm{ZnO}$ were prepared by the co-precipitation method, while catalysts containing $\mathrm{TiO}_{2}$ oxide were prepared by deposition-precipitation method. The catalytic activity of the investigated systems expressed as $\mathrm{H}_{2} / \mathrm{CO}$ ratio can be described by the following row: $\mathrm{Cu} / \mathrm{ZnO}>\mathrm{Cu} / \mathrm{TiO}_{2}>\mathrm{Au} / \mathrm{ZnO}>\mathrm{Au} / \mathrm{TiO}_{2}$, respectively. In contrast, the $\mathrm{CO}_{2} / \mathrm{CO}$ ratios formed during the investigated process for Au containing systems were higher than for $\mathrm{Cu}$ catalysts. Authors indicated that copper catalysts used in the OSRM process (reaction mixture- $\mathrm{CH}_{3} \mathrm{OH}-\mathrm{H}_{2} \mathrm{O}-\mathrm{O}_{2}$ in a molar ratio equal 1:1:0.2) at $200{ }^{\circ} \mathrm{C}$ exhibited a higher molar ratio of $\mathrm{H}_{2} / \mathrm{CO}$ compared to the process realized over gold-containing systems. However, the produced $\mathrm{CO}_{2} / \mathrm{CO}$ ratio in the final product obtained in the OSRM process over gold catalysts was higher than in the case of copper catalysts, which means that the use of a gold catalyst reduces the amount of $\mathrm{CO}$ generated in the reaction. In addition, the authors reported about lower activity of the $\mathrm{TiO}_{2}$ supported catalysts in the OSRM process. These results are related to the high selectivity of $\mathrm{TiO}_{2}$-containing systems towards methane formation, which reduces the amount of produced hydrogen. Figure 10 present the surface and gaseous species which are produced during the OSRM process. They have reported about undefined C-containing species (possibly polyoxymethylene or bidentate carbonate) formed during contact of the reaction mixture with the catalyst surface.

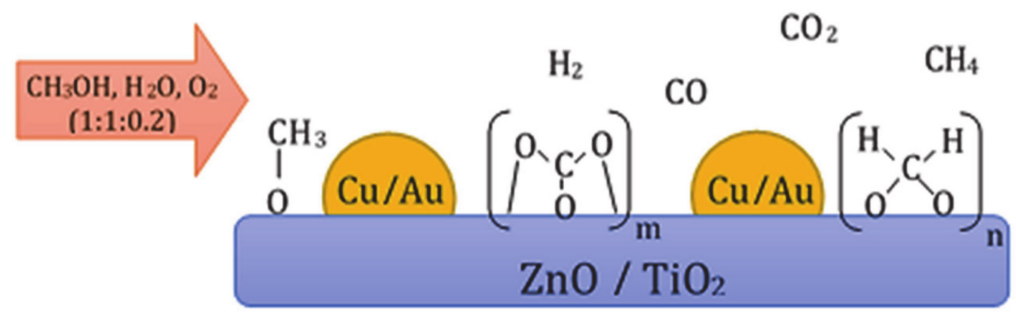

Figure 10. The species formed during the combined reforming of methanol process [117].

Literature data show that bimetallic catalysts $\mathrm{Ni}-\mathrm{Cu}$ have also been extensively studied in the oxy-steam reforming of both ethanol [118] and methanol reactions [119]. Catalytic tests of $\mathrm{Ni}_{\mathrm{x}} \mathrm{Cu}_{\mathrm{y}}-\mathrm{Al}$ catalysts with different $\mathrm{Ni}$ to $\mathrm{Cu}$ contents [120] carried out in the studied processes showed that the $\mathrm{Ni}$-Cu alloy containing catalyst had better performance in reforming of ethanol and methanol process compared to monometallic copper catalysts. It has also been shown that the introduction of $\mathrm{Cu}$ into nickel-based catalysts prevents carbon deposition and sintering of the active phase of catalysts used in the methanol-reforming process. The addition of $\mathrm{Cu}$ to the nickel catalyst also prevents the formation of methane and increases the stability of the Ni catalyst during the methanol-reforming process [119]. While, the addition of nickel into copper catalysts also improves $\mathrm{Cu}$ dispersion compared to the 
dispersion of copper species observed in the case of the $\mathrm{Cu} / \mathrm{ZnO} / \mathrm{Al}_{2} \mathrm{O}_{3}$ catalyst. The authors reported that a bimetallic $5 \% \mathrm{Ni}-5 \% \mathrm{Cu} / \mathrm{Al}_{2} \mathrm{O}_{3}$ catalyst was very active in both methane and methanol steam reforming reactions compared to commercial catalysts. Perez-Hernandez et al. [121] also studied $\mathrm{Cu} / \mathrm{ZrO}_{2}, \mathrm{Ni} / \mathrm{ZrO}_{2}$ and $\mathrm{Cu}-\mathrm{Ni} / \mathrm{ZrO}_{2}$ catalysts in oxidative steam reforming of methanol reaction in order to produce $\mathrm{H}_{2}$-rich gas at relatively low temperature (see the results presented in Table 4). The activity results showed that the monometallic $\mathrm{Ni} / \mathrm{ZrO}_{2}$ catalyst was more active than the $\mathrm{Cu} / \mathrm{ZrO}_{2}$ system in the OSRM reaction at higher temperatures. However, the bimetallic $\mathrm{Cu}-\mathrm{Ni} / \mathrm{ZrO}_{2}$ catalyst showed the best catalytic performance at low reaction temperatures compared to the monometallic catalysts. This activity result was attributed to the bimetallic nanoparticles present on the catalyst surface with different $\mathrm{Cu} / \mathrm{Ni}$ weight ratios. The investigated catalysts showed a similar selectivity toward $\mathrm{H}_{2}$ production equal about $60-70 \%$ at higher reaction temperatures. The $\mathrm{Cu}-\mathrm{Ni} / \mathrm{ZrO}_{2}$ system exhibited high selectivity toward $\mathrm{CO}$ formation, which is related to the presence of bimetallic nanoparticles on the catalyst surface. Mosinska et al. [4] also studied the bimetallic x Cu-y Ni (where x(y) = 10, 20 and $30 \mathrm{wt} . \%$ ) catalysts supported on binary oxides $\left(\mathrm{ZnO} \cdot \mathrm{Al}_{2} \mathrm{O}_{3}, \mathrm{CeO}_{2} \cdot \mathrm{Al}_{2} \mathrm{O}_{3}, \mathrm{ZrO}_{2} \cdot \mathrm{Al}_{2} \mathrm{O}_{3}\right)$, and the results are given in Table 4 . Authors reported that the hydrogen can be effectively produce in the OSRM process over an investigated $\mathrm{Cu}-\mathrm{Ni}$ catalyst systems. The $30 \% \mathrm{Cu}-10 \% \mathrm{Ni} / \mathrm{ZrO}_{2} \cdot \mathrm{Al}_{2} \mathrm{O}_{3}$ system was the most active system at $160{ }^{\circ} \mathrm{C}$. The high reactivity of this catalyst is related with the $\mathrm{Cu}_{0.8} \mathrm{Ni}_{0.2}$ alloy formation which was confirmed by XRD, ToF-SIMS and XPS techniques (see Figure 11).

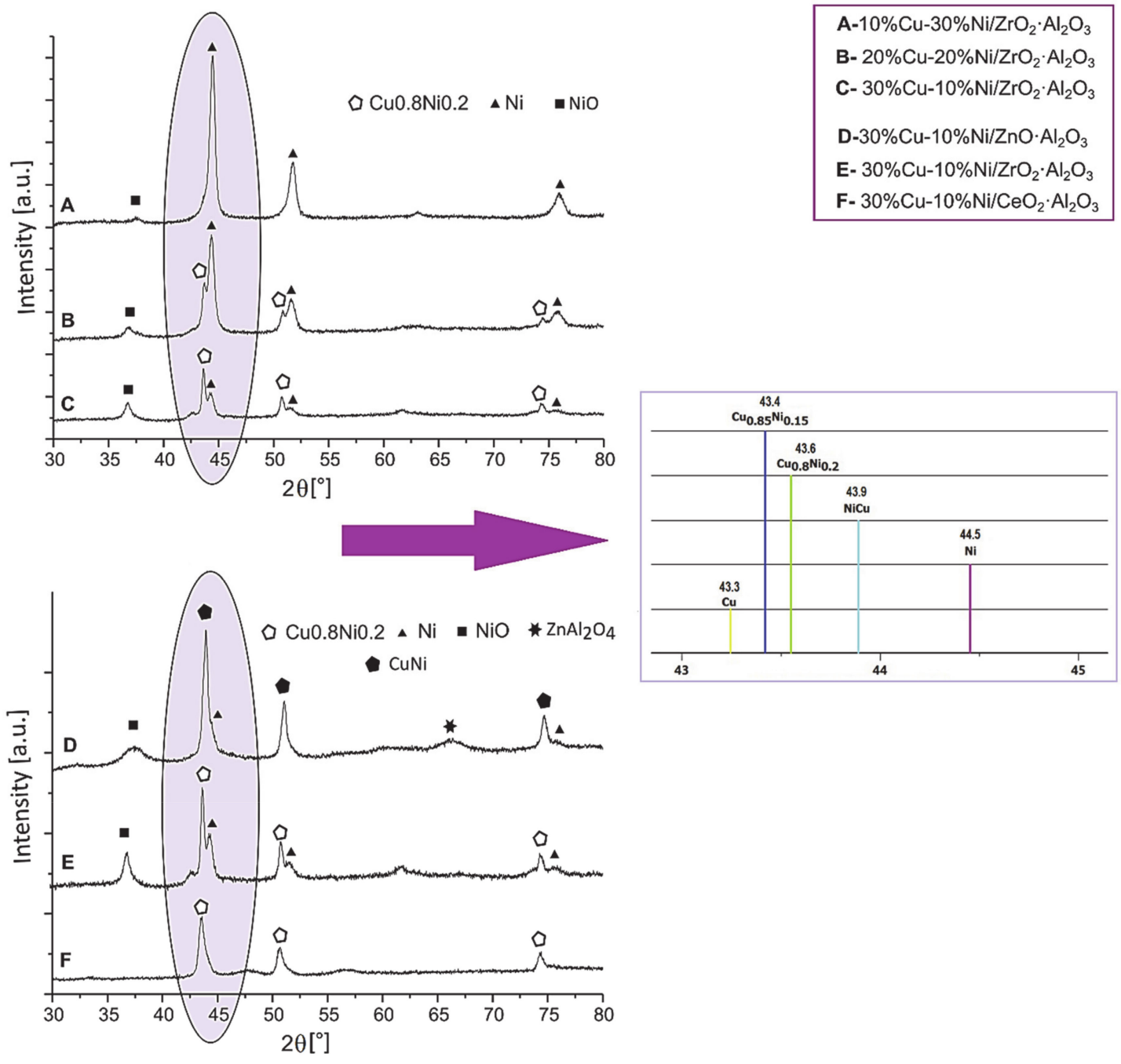

Figure 11. XRD patterns of spent bimetallic $\mathrm{Cu}-\mathrm{Ni}$ systems [4]. 
Table 4. The physicochemical and catalytic characterization of the various catalysts applied in OSR of methanol reaction.

\begin{tabular}{|c|c|c|c|c|c|c|c|c|c|c|c|c|c|c|c|}
\hline Catalyst & Preparation Method & $\begin{array}{c}\mathrm{S}_{\mathrm{BET}} \\
\left(\mathrm{m}^{2} / \mathrm{g}\right)\end{array}$ & $\begin{array}{l}\text { Metal Dispersion } \\
(\%)\end{array}$ & $\begin{array}{l}\text { Reduction } \\
\text { Temp. } \\
\left({ }^{\circ} \mathrm{C}\right)\end{array}$ & $\begin{array}{l}\text { Reduction } \\
\text { Time } \\
\text { (h) }\end{array}$ & $\frac{\mathrm{H}_{2} \mathrm{O}}{\text { methanol }}$ & $\frac{\mathrm{O}_{2}}{\text { methanol }}$ & $\begin{array}{c}\mathrm{W} / \mathrm{F} \\
\left(\mathrm{gscm}^{-3}\right)\end{array}$ & $\begin{array}{l}\text { GHSV } \\
\left(h^{-1}\right)\end{array}$ & $\begin{array}{l}\text { TOSR } \\
\left({ }^{\circ} \mathrm{C}\right)\end{array}$ & $\begin{array}{l}\text { Catalyst } \\
\text { Weight } \\
\text { (g) }\end{array}$ & $\begin{array}{c}\mathrm{CH}_{3} \mathrm{OH} \\
\text { Conv. } \\
(\%)\end{array}$ & $\mathrm{H}_{2}$ & $\mathrm{CO}$ & $\mathrm{CO}_{2}$ \\
\hline $\mathrm{CuO} / \mathrm{ZnO} / \mathrm{Al}_{2} \mathrm{O}_{3}[42]$ & $\mathrm{CP}$ & 94 & - & $350-450$ & 2 & 1.43 & 0.47 & - & - & 230 & 0.3 & 100.0 & $71.0^{\mathrm{y}}$ & $0.1^{\mathrm{y}}$ & $28.9^{\mathrm{y}}$ \\
\hline $\mathrm{Cu}_{0.30} \mathrm{Mn}_{0.70}[39]$ & UNC & 8 & - & 320 & 2 & 1.26 & 0.10 & 0.257 & - & 240 & 0.3 & 100.0 & $97.0^{\mathrm{s}}$ & $3.0^{\mathrm{s}}$ & - \\
\hline $\begin{array}{c}\mathrm{CuO}-\mathrm{CeO}_{2} \text { (mol.rat. }=0.15, \\
\mathrm{u} / \mathrm{n} \text { rat. }=1.2)[79]\end{array}$ & UNC & 10 & - & - & - & 1.50 & 0.10 & 0.257 & - & 300 & 0.3 & 56.0 & $90.3^{\mathrm{s}}$ & $2.1^{\mathrm{s}}$ & - \\
\hline $\begin{array}{c}\mathrm{CuO}-\mathrm{CeO}_{2} \text { (mol.rat. }=0.15, \\
\mathrm{u} / \mathrm{n} \text { rat. }=1.2)[79]\end{array}$ & UNC & 10 & - & - & - & 1.50 & 0.10 & 0.257 & - & 340 & 0.3 & 5.7 & $75.0^{\mathrm{s}}$ & $0.8^{\mathrm{s}}$ & - \\
\hline $\begin{array}{c}\mathrm{CuO}-\mathrm{CeO}_{2} \text { (mol.rat. }=0.15 \\
\mathrm{u} / \mathrm{n} \text { rat. }=2.38)[79]\end{array}$ & UNC & 5 & - & - & - & 1.50 & 0.10 & 0.257 & - & 300 & 0.3 & 45.0 & $84.3^{\mathrm{s}}$ & $4.8^{\mathrm{s}}$ & - \\
\hline $\begin{array}{c}\mathrm{CuO}-\mathrm{CeO}_{2} \text { (mol.rat. }=0.15 \\
\mathrm{u} / \mathrm{n} \text { rat. }=2.38)[79]\end{array}$ & UNC & 5 & - & - & - & 1.50 & 0.10 & 0.257 & - & 240 & 0.3 & 12.0 & $69.0^{\mathrm{s}}$ & $3.1^{\mathrm{s}}$ & - \\
\hline $\begin{array}{c}\mathrm{CuO}-\mathrm{CeO}_{2}(\text { mol.rat. }=0.15 \\
\mathrm{u} / \mathrm{n} \text { rat. }=3.30)[79]\end{array}$ & UNC & 20 & - & - & - & 1.50 & 0.10 & 0.257 & - & 300 & 0.3 & 95.0 & $96.6^{\mathrm{s}}$ & $3.4^{\mathrm{s}}$ & - \\
\hline $\begin{array}{c}\mathrm{CuO}-\mathrm{CeO}_{2}(\text { mol.rat. }=0.15 \\
\mathrm{u} / \mathrm{n} \text { rat. }=3.30)[79]\end{array}$ & UNC & 20 & - & - & - & 1.50 & 0.10 & 0.257 & - & 240 & 0.3 & 32.4 & $92.6^{\mathrm{s}}$ & $1.0^{\mathrm{s}}$ & - \\
\hline $\begin{array}{c}\mathrm{CuO}-\mathrm{CeO}_{2} \text { (mol.rat. }=0.15 \\
\mathrm{u} / \mathrm{n} \text { rat. }=4.17)[79]\end{array}$ & UNC & 43 & - & - & - & 1.50 & 0.10 & 0.257 & - & 300 & 0.3 & 100 & $95.9^{\mathrm{s}}$ & $4.0^{\mathrm{s}}$ & - \\
\hline $\begin{array}{c}\mathrm{CuO}-\mathrm{CeO}_{2} \text { (mol.rat. }=0.15 \\
\mathrm{u} / \mathrm{n} \text { rat. }=4.17)[79]\end{array}$ & UNC & 43 & - & - & - & 1.50 & 0.10 & 0.257 & - & 240 & 0.3 & 36.5 & $93.7^{\mathrm{s}}$ & $0.8^{\mathrm{s}}$ & - \\
\hline $\mathrm{Cu}(5) / \mathrm{CeO}_{2} \cdot \mathrm{Al}_{2} \mathrm{O}_{3}[91]$ & IP & 126 & $2.14^{*}$ & 300 & 1 & - & - & - & 26,700 & 200 & 0.2 & 97.7 & $69.1^{\mathrm{s}}$ & $0^{\mathrm{s}}$ & $30.6^{\mathrm{s}}$ \\
\hline $\mathrm{Cu}(20) / \mathrm{CeO}_{2} \cdot \mathrm{Al}_{2} \mathrm{O}_{3}[91]$ & IP & 101 & $0.16^{*}$ & 300 & 1 & - & - & - & 26,700 & 200 & 0.2 & 99.6 & $68.2^{\mathrm{s}}$ & $0^{\mathrm{s}}$ & $31.7^{\mathrm{s}}$ \\
\hline $\mathrm{Cu}(40) / \mathrm{CeO}_{2} \cdot \mathrm{Al}_{2} \mathrm{O}_{3}[91]$ & IP & 90 & $0.13 *$ & 300 & 1 & - & - & - & 26,700 & 200 & 0.2 & 87.9 & $65.7^{\mathrm{s}}$ & $0^{\mathrm{s}}$ & $33.8^{\mathrm{s}}$ \\
\hline $\mathrm{Cu}(60) / \mathrm{CeO}_{2} \cdot \mathrm{Al}_{2} \mathrm{O}_{3}[91]$ & IP & 30 & - & 300 & 1 & - & - & - & 26,700 & 200 & 0.2 & 9.6 & $28.5^{\mathrm{s}}$ & $0^{\mathrm{s}}$ & $71.5^{\mathrm{s}}$ \\
\hline $\mathrm{Ni}(5) / \mathrm{CeO}_{2} \cdot \mathrm{Al}_{2} \mathrm{O}_{3}[23]$ & IP & 132 & $1.06 *$ & 300 & 1 & - & - & - & 26,700 & 250 & 0.2 & 2 & $30.5^{\mathrm{s}}$ & - & $25^{\mathrm{s}}$ \\
\hline $\mathrm{Ni}(20) / \mathrm{CeO}_{2} \cdot \mathrm{Al}_{2} \mathrm{O}_{3}[23]$ & IP & 128 & $1.16^{*}$ & 300 & 1 & - & - & - & 26,700 & 250 & 0.2 & 31 & $33^{s}$ & - & $55.6^{\mathrm{s}}$ \\
\hline $\mathrm{Ni}(40) / \mathrm{CeO}_{2} \cdot \mathrm{Al}_{2} \mathrm{O}_{3}[23]$ & IP & 78 & $0.56^{*}$ & 300 & 1 & - & - & - & 26,700 & 250 & 0.2 & 98 & $68.9^{\mathrm{s}}$ & $13.3^{\mathrm{s}}$ & $14.3^{\mathrm{s}}$ \\
\hline $\mathrm{Ni}(60) / \mathrm{CeO}_{2} \cdot \mathrm{Al}_{2} \mathrm{O}_{3}[23]$ & IP & 133 & $0.69 *$ & 300 & 1 & - & - & - & 26,700 & 250 & 0.2 & 77 & $58.2^{\mathrm{s}}$ & $27.7^{\mathrm{s}}$ & $14.1^{\mathrm{s}}$ \\
\hline $\mathrm{Ni}(40) / \mathrm{CeO}_{2}[23]$ & IP & 34 & $0.63 *$ & 300 & 1 & - & - & - & 26,700 & 250 & 0.2 & 85 & $68.6^{\mathrm{s}}$ & $22.6^{\mathrm{s}}$ & $0.5^{\mathrm{s}}$ \\
\hline $\mathrm{Ni}(40) / \mathrm{Al}_{2} \mathrm{O}_{3}[23]$ & IP & 58 & $0.28^{*}$ & 300 & 1 & - & - & - & 26,700 & 250 & 0.2 & 20.5 & $53.4^{\mathrm{s}}$ & - & $25.2^{\mathrm{s}}$ \\
\hline $\mathrm{Pd}(2)-\mathrm{Ni}(40) / \mathrm{CeO}_{2} \cdot \mathrm{Al}_{2} \mathrm{O}_{3}[23]$ & SIP & 42 & - & 300 & 1 & - & - & - & 26,700 & 250 & 0.2 & 99.9 & $71.5^{\mathrm{s}}$ & $14.9^{\mathrm{s}}$ & $9.1^{\mathrm{s}}$ \\
\hline $\mathrm{Pd} / \mathrm{ZnO}[85]$ & IP & - & - & 400 & 2 & 1.50 & 0.10 & - & 110,000 & 250 & 0.3 & - & - & - & - \\
\hline $\mathrm{Pd} / \mathrm{ZnO}[85]$ & $\mathrm{CP}$ & - & - & 400 & 2 & 1.50 & 0.10 & - & 110,000 & 250 & 0.3 & - & - & - & - \\
\hline $\mathrm{Cu} / \mathrm{ZnO}[107]$ & $\mathrm{CP}$ & 49 & $9.6^{*}$ & $250-300$ & 1 & 1.30 & 0.20 & - & - & 300 & 0.5 & 90.0 & $\begin{array}{c}50.0 \\
\mathrm{~m}\end{array}$ & $\underset{\mathrm{m}}{0.07}$ & $\underset{\mathrm{m}}{20.0}$ \\
\hline $\mathrm{Cu} / \mathrm{ZnO} / \mathrm{Al}_{2} \mathrm{O}_{3}[107]$ & $\mathrm{CP}$ & 92 & $11.3^{*}$ & $250-300$ & 1 & 1.30 & 0.20 & - & - & 325 & 0.5 & 90.0 & - & $\underset{\mathrm{m}}{0.13}$ & - \\
\hline $\mathrm{Cu} / \mathrm{ZnO} / \mathrm{ZrO}_{2}[107]$ & $\mathrm{CP}$ & 82 & $13.2^{*}$ & $250-300$ & 1 & 1.30 & 0.20 & - & - & 295 & 0.5 & 90.0 & - & $\begin{array}{c}0.04 \\
\mathrm{~m}\end{array}$ & - \\
\hline $\mathrm{Cu} / \mathrm{ZnO} / \mathrm{ZrO}_{2} / \mathrm{Al}_{2} \mathrm{O}_{3}[107]$ & $\mathrm{CP}$ & 116 & $23.2 *$ & $250-300$ & 1 & 1.30 & 0.20 & - & - & 295 & 0.5 & 90.0 & - & $\underset{\mathrm{m}}{0.05}$ & - \\
\hline $\mathrm{Cu}(20) / \mathrm{ZrO}_{2} \cdot \mathrm{Al}_{2} \mathrm{O}_{3}(2: 1)[18]$ & IP & 143 & - & 300 & 1 & - & - & - & 26,700 & 200 & 0.2 & 22 & $41^{\mathrm{s}}$ & $0^{\mathrm{s}}$ & $59^{\mathrm{s}}$ \\
\hline $\mathrm{Cu}(20) / \mathrm{ZrO}_{2} \cdot \mathrm{Al}_{2} \mathrm{O}_{3}(1: 1)[18]$ & IP & 138 & - & 300 & 1 & - & - & - & 26,700 & 200 & 0.2 & 46 & $70^{\mathrm{s}}$ & $0^{\mathrm{s}}$ & $29^{\mathrm{s}}$ \\
\hline $\mathrm{Cu}(20) / \mathrm{ZrO}_{2} \cdot \mathrm{Al}_{2} \mathrm{O}_{3}(1: 2)[18]$ & IP & 167 & - & 300 & 1 & - & - & - & 26,700 & 200 & 0.2 & 58 & $68^{\mathrm{s}}$ & $0^{\mathrm{s}}$ & $31^{\mathrm{s}}$ \\
\hline $\mathrm{Ni}(20) / \mathrm{ZrO}_{2} \cdot \mathrm{Al}_{2} \mathrm{O}_{3}(1: 2)[18]$ & IP & 116 & - & 300 & 1 & - & - & - & 26,700 & 300 & 0.2 & 94 & $70^{\mathrm{s}}$ & $25^{\mathrm{s}}$ & $5^{\mathrm{s}}$ \\
\hline $\mathrm{Ni}(20) / \mathrm{ZrO}_{2} \cdot \mathrm{Al}_{2} \mathrm{O}_{3}(1: 2)[18]$ & IP & 116 & - & 500 & 1 & - & - & - & 26,700 & 300 & 0.2 & 61 & $65^{\mathrm{s}}$ & $0^{\mathrm{s}}$ & $22^{\mathrm{s}}$ \\
\hline
\end{tabular}


Table 4. Cont.

\begin{tabular}{|c|c|c|c|c|c|c|c|c|c|c|c|c|c|c|c|}
\hline Catalyst & Preparation Method & $\begin{array}{c}S_{\mathrm{BET}} \\
\left(\mathrm{m}^{2} / \mathrm{g}\right)\end{array}$ & $\begin{array}{c}\text { Metal Dispersion } \\
(\%)\end{array}$ & $\begin{array}{c}\text { Reduction } \\
\text { Temp. } \\
\left({ }^{\circ} \mathrm{C}\right)\end{array}$ & $\begin{array}{c}\text { Reduction } \\
\text { Time } \\
\text { (h) }\end{array}$ & $\frac{\mathrm{H}_{2} \mathrm{O}}{\text { methanol }}$ & $\frac{\mathrm{O}_{2}}{\text { methanol }}$ & $\begin{array}{c}\mathrm{W} / \mathrm{F} \\
\left(\mathrm{gscm}^{-3}\right)\end{array}$ & $\begin{array}{l}\text { GHSV } \\
\left(h^{-1}\right)\end{array}$ & $\begin{array}{l}\mathrm{T}_{\text {OSR }} \\
\left({ }^{\circ} \mathrm{C}\right)\end{array}$ & $\begin{array}{l}\text { Catalyst } \\
\text { Weight } \\
\text { (g) }\end{array}$ & $\begin{array}{c}\mathrm{CH}_{3} \mathrm{OH} \\
\text { Conv. } \\
(\%)\end{array}$ & $\mathrm{H}_{2}$ & $\mathrm{CO}$ & $\mathrm{CO}_{2}$ \\
\hline $\begin{array}{c}\mathrm{Pd}(1)-\mathrm{Cu}(20) / \\
\mathrm{ZrO}_{2} \cdot \mathrm{Al}_{2} \mathrm{O}_{3}(1: 2)[18]\end{array}$ & SIP & 171 & - & 300 & 1 & - & - & - & 26,700 & 200 & 0.2 & 60 & $66^{\mathrm{s}}$ & $0^{\mathrm{s}}$ & $33^{\mathrm{s}}$ \\
\hline $\begin{array}{c}\mathrm{Rh}(0.5)-\mathrm{Cu}(20) / \\
\mathrm{ZrO}_{2} \cdot \mathrm{Al}_{2} \mathrm{O}_{3}(1: 2)[18]\end{array}$ & SIP & - & - & 300 & 1 & - & - & - & 26,700 & 200 & 0.2 & 86 & $68^{\mathrm{s}}$ & $14^{\mathrm{s}}$ & $18^{\mathrm{s}}$ \\
\hline $\begin{array}{c}\mathrm{Rh}(1)-\mathrm{Cu}(20) / \\
\mathrm{ZrO}_{2} \cdot \mathrm{Al}_{2} \mathrm{O}_{3}(1: 2)[18]\end{array}$ & SIP & 164 & - & 300 & 1 & - & - & - & 26,700 & 200 & 0.2 & 74 & $71^{\mathrm{s}}$ & $4^{\mathrm{s}}$ & $25^{\mathrm{s}}$ \\
\hline $\begin{array}{c}\mathrm{Rh}(2)-\mathrm{Cu}(20) / \\
\mathrm{ZrO}_{2} \cdot \mathrm{Al}_{2} \mathrm{O}_{3}(1: 2)[18]\end{array}$ & SIP & - & - & 300 & 1 & - & - & - & 26,700 & 200 & 0.2 & 61 & $60^{\mathrm{s}}$ & $18^{\mathrm{s}}$ & $22^{\mathrm{s}}$ \\
\hline $\begin{array}{c}\mathrm{Pd}(1)-\mathrm{Ni}(20) / \\
\mathrm{ZrO}_{2} \cdot \mathrm{Al}_{2} \mathrm{O}_{3}(1: 2)[18]\end{array}$ & SIP & 120 & - & 300 & 1 & - & - & - & 26,700 & 200 & 0.2 & 58 & $63^{s}$ & $19^{\mathrm{s}}$ & $18^{\mathrm{s}}$ \\
\hline $\begin{array}{c}\mathrm{Rh}(1)-\mathrm{Ni}(20) / \\
\mathrm{ZrO}_{2} \cdot \mathrm{Al}_{2} \mathrm{O}_{3}(1: 2)[18]\end{array}$ & SIP & 123 & - & 300 & 1 & - & - & - & 26,700 & 200 & 0.2 & 66 & $64^{\mathrm{s}}$ & $18^{\mathrm{s}}$ & $18^{\mathrm{s}}$ \\
\hline $\mathrm{Ni}(20) / \mathrm{ZnO} \cdot \mathrm{Al}_{2} \mathrm{O}_{3}(2: 1)[22]$ & IP & 108 & - & 300 & 1 & - & - & - & 26,700 & 300 & 0.2 & 78 & $76^{s}$ & $0^{\mathrm{s}}$ & $24^{s}$ \\
\hline $\mathrm{Ni}(20) / \mathrm{ZnO} \cdot \mathrm{Al}_{2} \mathrm{O}_{3}(1: 1)[22]$ & IP & 123 & - & 300 & 1 & - & - & - & 26,700 & 300 & 0.2 & 99 & $76^{s}$ & $0^{\mathrm{s}}$ & $24^{\mathrm{s}}$ \\
\hline $\mathrm{Ni}(20) / \mathrm{ZnO} \cdot \mathrm{Al}_{2} \mathrm{O}_{3}(1: 2)[22]$ & IP & 231 & - & 300 & 1 & - & - & - & 26,700 & 300 & 0.2 & 73 & $40^{\mathrm{s}}$ & $10^{\mathrm{s}}$ & $24^{\mathrm{s}}$ \\
\hline $\mathrm{Ni}(20) / \mathrm{ZnO} \mathrm{Al}_{2} \mathrm{O}_{3}(1: 4)$ [22] & IP & 246 & - & 300 & 1 & - & - & - & 26,700 & 300 & 0.2 & 83 & $65^{\mathrm{s}}$ & $0^{\mathrm{s}}$ & $21^{\mathrm{s}}$ \\
\hline $\begin{array}{c}\mathrm{Pd}(0.5)-\mathrm{Ni}(20) / \\
\mathrm{ZnO} \cdot \mathrm{Al}_{2} \mathrm{O}_{3}(1: 1)[22]\end{array}$ & SIP & 106 & - & 300 & 1 & - & - & - & 26,700 & 300 & 0.2 & 99 & $73^{s}$ & $10^{\mathrm{s}}$ & $17^{\mathrm{s}}$ \\
\hline $\begin{array}{c}\mathrm{Pd}(2)-\mathrm{Ni}(20) / \\
\mathrm{ZnO} \cdot \mathrm{Al}_{2} \mathrm{O}_{3}(1: 1)[22]\end{array}$ & SIP & 104 & - & 300 & 1 & - & - & - & 26,700 & 300 & 0.2 & 99 & $72^{\mathrm{s}}$ & $8^{\mathrm{s}}$ & $20^{\mathrm{s}}$ \\
\hline $\mathrm{Pd}(6.5) / \mathrm{ZnO}[109]$ & $\mathrm{CP}$ & - & - & $400 / 500$ & 2 & 1.50 & 0.10 & - & - & 250 & 0.3 & - & - & - & - \\
\hline $\mathrm{Pd}(6.5) / \mathrm{ZnO}-\mathrm{ZrO}_{2}[109]$ & $\mathrm{CP}$ & - & - & $400 / 500$ & 2 & 1.50 & 0.10 & - & - & 250 & 0.3 & - & - & - & - \\
\hline $\mathrm{Pd}(6.5) / \mathrm{ZnO}-\mathrm{Fe}_{3} \mathrm{O}_{4}[109]$ & $\mathrm{CP}$ & - & - & $400 / 500$ & 2 & 1.50 & 0.10 & - & - & 250 & 0.3 & - & - & - & - \\
\hline $\mathrm{Pd}(6.5) / \mathrm{ZnO}-\mathrm{MgO}[109]$ & $\mathrm{CP}$ & - & - & $400 / 500$ & 2 & 1.50 & 0.10 & - & - & 250 & 0.3 & - & - & - & - \\
\hline $\mathrm{Pd} /(6.5) \mathrm{ZnO}-\mathrm{Cr}_{2} \mathrm{O}_{3}[109]$ & $\mathrm{CP}$ & - & - & $400 / 500$ & 2 & 1.50 & 0.10 & - & - & 250 & 0.3 & - & - & - & - \\
\hline $\mathrm{Pd} /(6.5) \mathrm{ZnO}-\mathrm{Al}_{2} \mathrm{O}_{3}[109]$ & $\mathrm{CP}$ & - & - & $400 / 500$ & 2 & 1.50 & 0.10 & - & - & 250 & 0.3 & - & - & - & - \\
\hline $\mathrm{Pd}(10) / \mathrm{ZnO}[92]$ & $\mathrm{CP}$ & - & - & $0-500$ & 1 & - & - & - & - & 300 & 0.1 & 100 & $67^{\mathrm{m}}$ & $6^{\mathrm{m}}$ & $27^{\mathrm{m}}$ \\
\hline $\mathrm{Pt}(10) / \mathrm{ZnO}[92]$ & $\mathrm{CP}$ & - & - & $0-500$ & 1 & - & - & - & - & 300 & 0.1 & 100 & $70^{\mathrm{m}}$ & $2^{\mathrm{m}}$ & $28^{\mathrm{m}}$ \\
\hline $\mathrm{Co}(10) / \mathrm{ZnO}$ [92] & $\mathrm{CP}$ & - & - & $0-500$ & 1 & - & - & - & - & 300 & 0.1 & 53 & $43^{\mathrm{m}}$ & $5^{\mathrm{m}}$ & $30^{\mathrm{m}}$ \\
\hline $\mathrm{Ni}(10) / \mathrm{ZnO}[92]$ & $\mathrm{CP}$ & - & - & $0-500$ & 1 & - & - & - & - & 300 & 0.1 & 96 & $54^{\mathrm{m}}$ & $23 \mathrm{~m}$ & $13^{\mathrm{m}}$ \\
\hline $\operatorname{Ir}(10) / \mathrm{ZnO}[92]$ & IP & - & - & $0-500$ & 1 & - & - & - & - & 300 & 0.1 & 59 & $49^{m}$ & $3^{\mathrm{m}}$ & $31^{\mathrm{m}}$ \\
\hline $\mathrm{Ru}(10) / \mathrm{ZnO}[92]$ & $\mathrm{CP}$ & - & - & $0-500$ & 1 & - & - & - & - & 300 & 0.1 & 88 & $48^{\mathrm{m}}$ & $25^{\mathrm{m}}$ & $11^{\mathrm{m}}$ \\
\hline $\mathrm{Pd}(10) / \mathrm{ZnO}[92]$ & $\mathrm{CP}$ & - & - & $0-500$ & 1 & - & - & - & - & 220 & 0.1 & 89 & $60^{\mathrm{m}}$ & $3^{\mathrm{m}}$ & $27^{\mathrm{m}}$ \\
\hline $\mathrm{Pd}(10) / \mathrm{SiO}_{2}[92]$ & $\mathrm{CP}$ & - & - & $0-500$ & 1 & - & - & - & - & 220 & 0.1 & 22 & $2^{\mathrm{m}}$ & $10^{\mathrm{m}}$ & $21^{\mathrm{m}}$ \\
\hline $\mathrm{Pd}(1) / \mathrm{CeO}_{2}[92]$ & $\mathrm{CP}$ & - & - & $0-500$ & 1 & - & - & - & - & 220 & 0.1 & 39 & $11^{\mathrm{m}}$ & $14^{\mathrm{m}}$ & $21^{\mathrm{m}}$ \\
\hline $\mathrm{Pd}(1) / \mathrm{ZnO}[92]$ & $\mathrm{CP}$ & - & - & $0-500$ & 1 & - & - & - & - & 220 & 0.1 & 55 & $35 \mathrm{~m}$ & $14^{\mathrm{m}}$ & $24^{\mathrm{m}}$ \\
\hline $\mathrm{Pd}(5) / \mathrm{ZnO}[92]$ & $\mathrm{CP}$ & - & - & $0-500$ & 1 & - & - & - & - & 220 & 0.1 & 80 & $60 \mathrm{~m}$ & $10^{\mathrm{m}}$ & $25^{\mathrm{m}}$ \\
\hline $\mathrm{Cu}(25) / \mathrm{ZnO}[92]$ & $\mathrm{CP}$ & - & - & $0-500$ & 1 & - & - & - & - & 220 & 0.1 & 99 & $20^{c}$ & - & - \\
\hline $\mathrm{Cu}(25) / \mathrm{ZrO}_{2}[92]$ & IP & - & - & $0-500$ & 1 & - & - & - & - & 220 & 0.1 & 75 & $13^{c}$ & - & - \\
\hline $\mathrm{Cu}(25) / \mathrm{SiO}_{2}[92]$ & IP & - & - & $0-500$ & 1 & - & - & - & - & 220 & 0.1 & 5 & $0.1^{\mathrm{c}}$ & - & - \\
\hline $\mathrm{Cu} / \mathrm{ZrO}_{2}[121]$ & DP & 33 & - & $25-300$ & 1 & - & - & - & 30,000 & 310 & 0.1 & 40 & $68^{\mathrm{m}}$ & $2^{\mathrm{m}}$ & $98^{\mathrm{m}}$ \\
\hline $\mathrm{Cu} / \mathrm{ZrO}_{2}[121]$ & $\mathrm{DP}$ & 33 & - & $25-300$ & 1 & - & - & - & 30,000 & 350 & 0.1 & 50 & $70^{\mathrm{m}}$ & $10^{\mathrm{m}}$ & $90^{\mathrm{m}}$ \\
\hline $\mathrm{Ni} / \mathrm{ZrO}_{2}[121]$ & $\mathrm{DP}$ & 34 & - & $25-300$ & 1 & - & - & - & 30,000 & 310 & 0.1 & 30 & $60^{\mathrm{m}}$ & $19^{\mathrm{m}}$ & $80^{\mathrm{m}}$ \\
\hline $\mathrm{Ni} / \mathrm{ZrO}_{2}[121]$ & DP & 34 & - & $25-300$ & 1 & - & - & - & 30,000 & 350 & 0.1 & 100 & $62^{\mathrm{m}}$ & $80^{\mathrm{m}}$ & $15^{\mathrm{m}}$ \\
\hline
\end{tabular}


Table 4. Cont.

\begin{tabular}{|c|c|c|c|c|c|c|c|c|c|c|c|c|c|c|c|}
\hline Catalyst & Preparation Method & $\begin{array}{c}\mathrm{S}_{\mathrm{BET}} \\
\left(\mathrm{m}^{2} / \mathrm{g}\right)\end{array}$ & $\begin{array}{c}\text { Metal Dispersion } \\
(\%)\end{array}$ & $\begin{array}{l}\text { Reduction } \\
\text { Temp. } \\
\left({ }^{\circ} \mathrm{C}\right)\end{array}$ & $\begin{array}{l}\text { Reduction } \\
\text { Time } \\
\text { (h) }\end{array}$ & $\frac{\mathrm{H}_{2} \mathrm{O}}{\text { methanol }}$ & $\frac{\mathrm{O}_{2}}{\text { methanol }}$ & $\begin{array}{c}\mathrm{W} / \mathrm{F} \\
\left(\mathrm{gscm}^{-3}\right)\end{array}$ & $\begin{array}{c}\text { GHSV } \\
\left(h^{-1}\right)\end{array}$ & $\begin{array}{l}\mathrm{T}_{\mathrm{OSR}} \\
\left({ }^{\circ} \mathrm{C}\right)\end{array}$ & $\begin{array}{l}\text { Catalyst } \\
\text { Weight } \\
\text { (g) }\end{array}$ & $\begin{array}{c}\mathrm{CH}_{3} \mathrm{OH} \\
\text { Conv. } \\
(\%)\end{array}$ & $\mathbf{H}_{2}$ & $\mathrm{CO}$ & $\mathrm{CO}_{2}$ \\
\hline $\mathrm{Cu}-\mathrm{Ni} / \mathrm{ZrO}_{2}[121]$ & DP & 35 & - & $25-300$ & 1 & - & - & - & 30,000 & 310 & 0.1 & 90 & $72^{\mathrm{m}}$ & $87^{m}$ & $13^{\mathrm{m}}$ \\
\hline $\mathrm{Cu}-\mathrm{Ni} / \mathrm{ZrO}_{2}[121]$ & DP & 35 & - & $25-300$ & 1 & - & - & - & 30,000 & 350 & 0.1 & 99 & $63^{\mathrm{m}}$ & $80^{\mathrm{m}}$ & $20^{\mathrm{m}}$ \\
\hline $\begin{array}{l}\mathrm{Cu}(10)-\mathrm{Ni}(30) / \\
\mathrm{ZrO}_{2} \cdot \mathrm{Al}_{2} \mathrm{O}_{3}[4]\end{array}$ & CIP & 120 & - & 300 & 1 & - & - & - & 26,700 & 160 & 0.2 & 22 & $3.0^{\mathrm{y}}$ & $0^{\mathrm{s}}$ & $100^{\mathrm{s}}$ \\
\hline $\begin{array}{l}\mathrm{Cu}(10)-\mathrm{Ni}(30) / \\
\mathrm{ZrO}_{2} \cdot \mathrm{Al}_{2} \mathrm{O}_{3}[4]\end{array}$ & CIP & 120 & - & 300 & 1 & - & - & - & 26,700 & 200 & 0.2 & 85 & $2.2^{\mathrm{y}}$ & $48^{\mathrm{s}}$ & $52^{\mathrm{s}}$ \\
\hline $\begin{array}{l}\mathrm{Cu}(20)-\mathrm{Ni}(20) / \\
\mathrm{ZrO}{ }_{2} \cdot \mathrm{Al}_{2} \mathrm{O}_{3}[4]\end{array}$ & CIP & 142 & - & 300 & 1 & - & - & - & 26,700 & 160 & 0.2 & 35 & $3.0^{\mathrm{y}}$ & $0^{\mathrm{s}}$ & $100^{s}$ \\
\hline $\begin{array}{l}\mathrm{Cu}(20)-\mathrm{Ni}(20) / \\
\mathrm{ZrO}_{2} \cdot \mathrm{Al}_{2} \mathrm{O}_{3}[4]\end{array}$ & CIP & 142 & - & 300 & 1 & - & - & - & 26,700 & 200 & 0.2 & 86 & $2.0^{\mathrm{y}}$ & $48^{\mathrm{s}}$ & $52^{\mathrm{s}}$ \\
\hline $\begin{array}{l}\mathrm{Cu}(30)-\mathrm{Ni}(10) / \\
\mathrm{ZrO}_{2} \cdot \mathrm{Al}_{2} \mathrm{O}_{3}[4]\end{array}$ & CIP & 119 & - & 300 & 1 & - & - & - & 26,700 & 160 & 0.2 & 79 & $3.0^{\mathrm{y}}$ & $0^{\mathrm{s}}$ & $100^{s}$ \\
\hline $\begin{array}{l}\mathrm{Cu}(30)-\mathrm{Ni}(10) / \\
\mathrm{ZrO}{ }_{2} \cdot \mathrm{Al}_{2} \mathrm{O}_{3}[4]\end{array}$ & CIP & 119 & - & 300 & 1 & - & - & - & 26,700 & 200 & 0.2 & 91 & $2.3^{\mathrm{y}}$ & $39^{\mathrm{s}}$ & $61^{\mathrm{s}}$ \\
\hline $\begin{array}{l}\mathrm{Cu}(30)-\mathrm{Ni}(10) / \\
\mathrm{CeO}_{2} \cdot \mathrm{Al}_{2} \mathrm{O}_{3}[4]\end{array}$ & CIP & 120 & - & 300 & 1 & - & - & - & 26,700 & 160 & 0.2 & 26 & $3.0^{\mathrm{y}}$ & $0^{\mathrm{s}}$ & $100^{\mathrm{s}}$ \\
\hline $\begin{array}{l}\mathrm{Cu}(30)-\mathrm{Ni}(10) / \\
\mathrm{CeO}_{2} \cdot \mathrm{Al}_{2} \mathrm{O}_{3}[4]\end{array}$ & CIP & 120 & - & 300 & 1 & - & - & - & 26,700 & 200 & 0.2 & 96 & $2.1^{\mathrm{y}}$ & $30^{\mathrm{s}}$ & $70^{\mathrm{s}}$ \\
\hline $\begin{array}{l}\mathrm{Cu}(30)-\mathrm{Ni}(10) / \\
\mathrm{ZnO} \cdot \mathrm{Al}_{2} \mathrm{O}_{3}[4]\end{array}$ & CIP & 150 & - & 300 & 1 & - & - & - & 26,700 & 160 & 0.2 & 19 & $3.0^{\mathrm{y}}$ & $0^{s}$ & $100^{\mathrm{s}}$ \\
\hline $\begin{array}{l}\mathrm{Cu}(30)-\mathrm{Ni}(10) / \\
\mathrm{ZnO} \cdot \mathrm{Al}_{2} \mathrm{O}_{3}[4]\end{array}$ & CIP & 150 & - & 300 & 1 & - & - & - & 26,700 & 200 & 0.2 & 87 & $2.3^{y}$ & $23^{s}$ & $77^{\mathrm{s}}$ \\
\hline $\mathrm{Cu}(20) / \mathrm{MWCNTs}$ [112] & IP & 290 & $0.35 *$ & 300 & 1 & - & - & - & 26,700 & 200 & 0.1 & 11 & $33^{\mathrm{s}}$ & $0^{\mathrm{s}}$ & $62^{\mathrm{s}}$ \\
\hline $\mathrm{Cu}(20) / \mathrm{MWCNTs}$ [112] & IP & 290 & $0.35 *$ & 300 & 1 & - & - & - & 26,700 & 300 & 0.1 & 75 & $63^{s}$ & $8.5^{\mathrm{s}}$ & $28.5^{\mathrm{s}}$ \\
\hline $\mathrm{Ni}(20) / \mathrm{MWCNTs}$ [17] & IP & 271 & - & 300 & 1 & - & - & - & 26,700 & 200 & 0.1 & 7.5 & $78.5^{\mathrm{s}}$ & $0^{\mathrm{s}}$ & $21.5^{\mathrm{s}}$ \\
\hline $\mathrm{Ni}(20) / \mathrm{MWCNTs}[17]$ & IP & 271 & - & 300 & 1 & - & - & - & 26,700 & 300 & 0.1 & 99.7 & $67.6^{\mathrm{s}}$ & $16.5^{\mathrm{s}}$ & $15.9^{\mathrm{s}}$ \\
\hline $\mathrm{Au}(1)-\mathrm{Cu}(20) / \mathrm{MWCNTs}$ [111] & DP & 272 & - & 300 & 1 & - & - & - & 26,700 & 200 & 0.1 & 14 & $29.8^{\mathrm{s}}$ & $0^{\mathrm{s}}$ & $70.2^{\mathrm{s}}$ \\
\hline $\mathrm{Au}(1)-\mathrm{Cu}(20) / \mathrm{MWCNTs}$ [111] & DP & 272 & - & 300 & 1 & - & - & - & 26,700 & 300 & 0.1 & 83 & $73^{s}$ & $8.6^{\mathrm{s}}$ & $18.4^{\mathrm{s}}$ \\
\hline $\mathrm{Au}(1)-\mathrm{Ni}(20) / \mathrm{MWCNTs}[17]$ & DP & 311 & - & 300 & 1 & - & - & - & 26,700 & 200 & 0.1 & 8 & $63.2^{\mathrm{s}}$ & $0^{\mathrm{s}}$ & $36.8^{\mathrm{s}}$ \\
\hline $\mathrm{Au}(1)-\mathrm{Ni}(20) / \mathrm{MWCNTs}[17]$ & DP & 311 & - & 300 & 1 & - & - & - & 26,700 & 300 & 0.1 & 99.8 & $70.4^{\mathrm{s}}$ & $0^{\mathrm{s}}$ & $29.6^{\mathrm{s}}$ \\
\hline
\end{tabular}

*-based on chemisorption measurement; IP-impregnation method, SIP-subsequent impregnation method, CIP-co-impregnation method, CP-co-precipitation method, $\mathrm{DP}-$ deposition-precipitation method, UNC-urea nitrate combustion method, $\mathrm{S}_{\mathrm{BET}}$ - specific surface area, $\mathrm{y}-\mathrm{yield}$ of the product (\%), s-selectivity of the product (\%), $\mathrm{c}-\mathrm{concentration}$ of the product $(\%), \mathrm{m}-$ level in product gas $(\mathrm{mol} \%)$. 
In addition, the most active system in the studied process at $200^{\circ} \mathrm{C}$ was $30 \% \mathrm{Cu}-10 \% \mathrm{Ni} / \mathrm{CeO}_{2} \cdot \mathrm{Al}_{2} \mathrm{O}_{3}$ catalyst. This catalytic system was easily reducible and showed the presence of the $\mathrm{Cu} 0.8 \mathrm{Ni} 0.2$ alloy on its surface. The authors also confirmed that the alloy composition is an important parameter influencing the reactivity of the bimetallic $\mathrm{Cu}-\mathrm{Ni}$ catalysts in the OSRM process. At the same time, the bimetallic $30 \% \mathrm{Cu}-10 \% \mathrm{Ni} / \mathrm{ZnO} \cdot \mathrm{Al}_{2} \mathrm{O}_{3}$ catalyst containing the equimolar $\mathrm{Cu}-\mathrm{Ni}$ alloy and irreducible support showed the lowest activity in the studied oxy-steam-reforming of methanol reaction. The authors of the work [122] investigated the catalytic activity of the $\mathrm{Au} / \mathrm{CeO}_{2}-0.135$ system in the OSRM process. The results showed that it has the highest methanol conversion and the $\mathrm{H}_{2}$ production rate for oxidative steam reforming of methanol (OSRM). The reducibility and gold particle size played a crucial role in determining the $\mathrm{H}_{2} / \mathrm{CO}_{2}$ ratio at the temperature of $200^{\circ} \mathrm{C}$. The authors reported that the reducibility of the catalytic material, small gold particle size and cationing gold centers as active sites play a crucial role in the catalytic activity of prepared catalysts in the OSRM process. Wang et al. [123] reported the high activity of the $\mathrm{ZnO}-\mathrm{Cr}_{2} \mathrm{O}_{3} / \mathrm{CeO}_{2}-\mathrm{ZrO}_{2}$ catalyst in oxidative steam reforming of methanol at higher temperatures, which exhibited fast reaction rates compared to conventional $\mathrm{Cu}$-based catalyst. The investigated catalysts produced much lower $\mathrm{CO}$ compared to the $\mathrm{Cu}$ catalyst and can be used to determine detailed kinetic modeling and design of optimal parameters of the OSRM reactors.

\section{Conclusions}

This work provides valuable information about catalyst systems used in reforming methanol processes. This paper sheds light on the role of the catalyst in oxy-steam reforming of methanol reaction and presents possible methods of modification of catalytic systems in order to achieve high active, stable and selective catalysts of this process. It was shown that the selection of the suitable preparation method, type of support, the addition of promoters to copper, nickel or transition metal catalysts have a great influence on the catalyst performance in the OSRM reaction. The mechanism of the OSRM process on the copper-based catalyst surface was also discussed. However, it is still a controversial issue to show the clear approach of the OSRM mechanism. In this review, we presented the latest data concerning the catalytic materials and mechanism approach applied in the oxy-steam reforming of methanol process. The presented data may become the basis for the development of the industrial catalyst used in the methanol processing reaction and may also contribute to the development of new technologies based on fuel cells.

Author Contributions: The work was designed and presented by M.M., M.I.S.-J. and P.M. All authors have read and agreed to the published version of the manuscript.

Funding: The work was funded by the National Science Center within the "OPUS" Program, Poland (Grant no. 2018/29/B/ST8/01317).

Conflicts of Interest: The authors declare no conflict of interest. 


\section{Abbreviations}

$\begin{array}{ll}\text { ATRM } & \text { Autothermal reforming of methanol } \\ \text { CIP } & \text { Co-impregnation method } \\ \text { CNTs } & \text { Carbon nanotubes } \\ \text { CP } & \text { Co-precipitation method } \\ \text { CRM } & \text { Combined (oxy-steam) reforming of methanol } \\ \text { DME } & \text { Dimethyl ether } \\ \text { DMFC } & \text { Direct methanol fuel cell } \\ \text { DP } & \text { Deposition-precipitation method } \\ \text { FTIR } & \text { Fourier-transform infrared spectroscopy } \\ \text { GHSV } & \text { Gas hourly space velocity } \\ \text { IP } & \text { Impregnation method } \\ \text { MD } & \text { Decomposition of methanol } \\ \text { MWCNTs } & \text { Multiwalled carbon nanotubes } \\ \text { OSR } & \text { Oxy-steam-reforming of methanol } \\ \text { POM } & \text { Partial oxidation of methanol } \\ \text { RDS } & \text { Rate-determining step } \\ \text { RWGS } & \text { Reverse water gas shift } \\ \text { SBET } & \text { Specific surface area } \\ \text { SIP } & \text { Subsequent impregnation method } \\ \text { SMSI } & \text { Strong metal-support interaction } \\ \text { SRM } & \text { Steam reforming of methanol } \\ \text { TOM } & \text { Total oxidation of methanol } \\ \text { UNC } & \text { Urea nitrate combustion method } \\ \text { W/F } & \text { Catalyst weight/volume flow rate ratio } \\ \text { WGS } & \text { Water-gas shift } \\ \text { XANES } & \text { X-ray absorption near edge structure } \\ \text { XPS } & \text { X-ray photoelectron spectroscopy } \\ \text { XRD } & \text { X-ray diffraction spectroscopy } \\ & \end{array}$

\section{References}

1. Salvi, B.L.; Subramanian, K.A.; Panwar, N.L. Alternative fuels for transportation vehicles: A technical review. Renew. Sustain. Energy Rev. 2013, 25, 404-419. [CrossRef]

2. He, L.-Y.; Qiu, L.-Y. Transport demand, harmful emissions, environment and health co-benefits in China. Energy Policy 2016, 97, 267-275. [CrossRef]

3. Mierczynski, P.; Vasilev, K.; Mierczynska, A.; Maniukiewicz, W.; Maniecki, T.P. Highly selective $\mathrm{Pd}-\mathrm{Cu} / \mathrm{ZnAl}_{2} \mathrm{O}_{4}$ catalyst for hydrogen production. Appl. Catal. A Gen. 2014, 479, 26-34. [CrossRef]

4. Mosinska, M.; Stępińska, N.; Maniukiewicz, W.; Rogowski, J.; Mierczynska-Vasilev, A.; Vasilev, K.; Szynkowska, M.I.; Mierczynski, P. Hydrogen Production on Cu-Ni Catalysts via the Oxy-Steam Reforming of Methanol. Catalysts 2020, 10, 273. [CrossRef]

5. Alves, H.J.; Bley Junior, C.; Niklevicz, R.R.; Frigo, E.P.; Frigo, M.S.; Coimbra-Araújo, C.H. Overview of hydrogen production technologies from biogas and the applications in fuel cells. Int. J. Hydrog. Energy 2013, 38, 5215-5225. [CrossRef]

6. Mierczynski, P. Comparative Studies of Bimetallic $\mathrm{Ru}-\mathrm{Cu}, \mathrm{Rh}-\mathrm{Cu}, \mathrm{Ag}-\mathrm{Cu}, \mathrm{Ir}-\mathrm{Cu}$ Catalysts Supported on ZnO-Al2O3, ZrO2-Al2O3 Systems. Catal. Lett. 2016, 146, 1825-1837. [CrossRef]

7. Echigo, M.; Tabata, T. A study of CO removal on an activated Ru catalyst for polymer electrolyte fuel cell applications. Appl. Catal. A Gen. 2003, 251, 157-166. [CrossRef]

8. Grochala, W.; Edwards, P.P. Thermal Decomposition of the Non-Interstitial Hydrides for the Storage and Production of Hydrogen. Chem. Rev. 2004, 104, 1283-1316. [CrossRef]

9. Samimi, F.; Rahimpour, M.R. Chapter 14-Direct Methanol Fuel Cell. In Methanol; Basile, A., Dalena, F., Eds.; Elsevier: Amsterdam, The Netherlands, 2018; pp. 381-397.

10. Adhikari, S.; Fernando, S.D.; Haryanto, A. Hydrogen production from glycerol: An update. Energy Convers. Manag. 2009, 50, 2600-2604. [CrossRef] 
11. Agrell, J.; Boutonnet, M.; Melián-Cabrera, I.; Fierro, J. Production of hydrogen from methanol over binary $\mathrm{Cu} / \mathrm{ZnO}$ catalysts. Appl. Catal. A Gen. 2003, 253, 201-211. [CrossRef]

12. Alejo, L.; Lago, R.; Peña, M.A.; Fierro, J.L.G. Partial oxidation of methanol to produce hydrogen over Cu Zn-based catalysts. Appl. Catal. A Gen. 1997, 162, 281-297. [CrossRef]

13. Azadi, P.; Otomo, J.; Hatano, H.; Oshima, Y.; Farnood, R. Hydrogen production by catalytic near-critical water gasification and steam reforming of glucose. Int. J. Hydrog. Energy 2010, 35, 3406-3414. [CrossRef]

14. Bae, J.; Lee, S.; Kim, S.; Oh, J.; Choi, S.; Bae, M.; Kang, I.; Katikaneni, S.P. Liquid fuel processing for hydrogen production: A review. Int. J. Hydrog. Energy 2016, 41, 19990-20022. [CrossRef]

15. Zhao, X.-l.; LÜ, Y.-a.; Liao, W.-p.; Jin, M.-s.; Suo, Z.-h. Hydrogen production from steam reforming of ethylene glycol over supported nickel catalysts. J. Fuel Chem. Technol. 2015, 43, 581-588. [CrossRef]

16. Profeti, L.P.R.; Ticianelli, E.A.; Assaf, E.M. Production of hydrogen via steam reforming of biofuels on $\mathrm{Ni} / \mathrm{CeO}_{2}-\mathrm{Al}_{2} \mathrm{O}_{3}$ catalysts promoted by noble metals. Int. J. Hydrog. Energy 2009, 34, 5049-5060. [CrossRef]

17. Mierczynski, P.; Vasilev, K.; Mierczynska, A.; Maniukiewicz, W.; Szynkowska, M.I.; Maniecki, T.P. Bimetallic $\mathrm{Au}-\mathrm{Cu}, \mathrm{Au}-\mathrm{Ni}$ catalysts supported on MWCNTs for oxy-steam reforming of methanol. Appl. Catal. B Environ. 2016, 185, 281-294. [CrossRef]

18. Mierczynski, P.; Mosinska, M.; Maniukiewicz, W.; Vasilev, K.; Szynkowska, M.I. Novel Rh(Pd)-Cu(Ni) supported catalysts for oxy-steam reforming of methanol. Arab. J. Chem. 2020, 13, 3183-3195. [CrossRef]

19. Mierczynski, P.; Mierczynska, A.; Maniukiewicz, W.; Maniecki, T.P.; Vasilev, K. MWCNTs as a catalyst in oxy-steam reforming of methanol. RSC Adv. 2016, 6, 81408-81413. [CrossRef]

20. Barthos, R.; Solymosi, F. Hydrogen production in the decomposition and steam reforming of methanol on $\mathrm{Mo}_{2} \mathrm{C} /$ carbon catalysts. J. Catal. 2007, 249, 289-299. [CrossRef]

21. Wang, J.B.; Li, C.-H.; Huang, T.-J. Study of Partial Oxidative Steam Reforming of Methanol over $\mathrm{Cu}-\mathrm{ZnO} /$ samaria-doped Ceria Catalyst. Catal. Lett. 2005, 103, 239-247. [CrossRef]

22. Mierczynski, P.; Mosinska, M.; Zakrzewski, M.; Dawid, B.; Ciesielski, R.; Maniukiewicz, W.; Maniecki, T. Influence of the $\mathrm{Zn}-\mathrm{Al}$ binary oxide composition on the physicochemical and catalytic properties of $\mathrm{Ni}$ catalysts in the oxy-steam reforming of methanol. React. Kinet. Mech. Catal. 2017, 121, 453-472. [CrossRef]

23. Mierczynski, P.; Mierczynska, A.; Ciesielski, R.; Mosinska, M.; Nowosielska, M.; Czylkowska, A.; Maniukiewicz, W.; Szynkowska, I.M.; Vasilev, K. High Active and Selective Ni/CeO2-Al2O3 and $\mathrm{Pd}-\mathrm{Ni} / \mathrm{CeO}_{2}-\mathrm{Al}_{2} \mathrm{O}_{3}$ Catalysts for Oxy-Steam Reforming of Methanol. Catalysts 2018, 8. [CrossRef]

24. Geissler, K.; Newson, E.; Vogel, F.; Truong, T.-B.; Hottinger, P.; Wokaun, A. Autothermal methanol reforming for hydrogen production in fuel cell applications. Phys. Chem. Chem. Phys. 2001, 3, 289-293. [CrossRef]

25. Abrokwah, R.Y.; Deshmane, V.G.; Kuila, D. Comparative performance of M-MCM-41 (M: Cu, Co, Ni, Pd, Zn and Sn) catalysts for steam reforming of methanol. J. Mol. Catal. A Chem. 2016, 425, 10-20. [CrossRef]

26. Ahn, S.H.; Kwon, O.J.; Choi, I.; Kim, J.J. Synergetic effect of combined use of Cu-ZnO-Al2O3 and Pt-Al2O3 for the steam reforming of methanol. Catal. Commun. 2009, 10, 2018-2022. [CrossRef]

27. Chang, C.-C.; Chang, C.-T.; Chiang, S.-J.; Liaw, B.-J.; Chen, Y.-Z. Oxidative steam reforming of methanol over $\mathrm{CuO} / \mathrm{ZnO} / \mathrm{CeO} / \mathrm{ZrO} 2 / \mathrm{Al} 2 \mathrm{O} 3$ catalysts. Int. J. Hydrog. Energy 2010, 35, 7675-7683. [CrossRef]

28. Chang, C.-C.; Hsu, C.-C.; Chang, C.-T.; Chen, Y.-P.; Liaw, B.-J.; Chen, Y.-Z. Effect of noble metal on oxidative steam reforming of methanol over $\mathrm{CuO} / \mathrm{ZnO} / \mathrm{Al} 2 \mathrm{O} 3$ catalysts. Int. J. Hydrog. Energy 2012, 37, 11176-11184. [CrossRef]

29. Clancy, P.; Breen, J.P.; Ross, J.R.H. The preparation and properties of coprecipitated Cu-Zr-Y and Cu-Zr-La catalysts used for the steam reforming of methanol. Catal. Today 2007, 127, 291-294. [CrossRef]

30. Jeong, H.; Kim, K.I.; Kim, T.H.; Ko, C.H.; Park, H.C.; Song, I.K. Hydrogen production by steam reforming of methanol in a micro-channel reactor coated with $\mathrm{Cu} / \mathrm{ZnO} / \mathrm{ZrO}_{2} / \mathrm{Al}_{2} \mathrm{O}_{3}$ catalyst. J. Power Sources 2006, 159, 1296-1299. [CrossRef]

31. Das, D.; Llorca, J.; Dominguez, M.; Colussi, S.; Trovarelli, A.; Gayen, A. Methanol steam reforming behavior of copper impregnated over $\mathrm{CeO} 2-\mathrm{ZrO} 2$ derived from a surfactant assisted coprecipitation route. Int. J. Hydrog. Energy 2015, 40, 10463-10479. [CrossRef]

32. Yong-Feng, L.; Xin-Fa, D.; Wei-Ming, L. Effects of ZrO2-promoter on catalytic performance of CuZnAlO catalysts for production of hydrogen by steam reforming of methanol. Int. J. Hydrog. Energy 2004, 29, 1617-1621. [CrossRef]

33. Lindström, B.; Pettersson, L.J.; Govind Menon, P. Activity and characterization of $\mathrm{Cu} / \mathrm{Zn}, \mathrm{Cu} / \mathrm{Cr}$ and $\mathrm{Cu} / \mathrm{Zr}$ on $\gamma$-alumina for methanol reforming for fuel cell vehicles. Appl. Catal. A Gen. 2002, 234, 111-125. [CrossRef] 
34. Ilinich, O.M.; Liu, Y.; Waterman, E.M.; Farrauto, R.J. Kinetics of Methanol Steam Reforming with a $\mathrm{Pd}-\mathrm{Zn}-\mathrm{Y} / \mathrm{CeO} 2$ Catalyst under Realistic Operating Conditions of a Portable Reformer in Fuel Cell Applications. Ind. Eng. Chem. Res. 2013, 52, 638-644. [CrossRef]

35. Sá, S.; Silva, H.; Brandão, L.; Sousa, J.M.; Mendes, A. Catalysts for methanol steam reforming-A review. Appl. Catal. B Environ. 2010, 99, 43-57. [CrossRef]

36. Talkhoncheh, S.K.; Haghighi, M.; Minaei, S.; Ajamein, H.; Abdollahifar, M. Synthesis of CuO/ZnO/Al2O3/ $\mathrm{ZrO} 2 / \mathrm{CeO} 2$ nanocatalysts via homogeneous precipitation and combustion methods used in methanol steam reforming for fuel cell grade hydrogen production. RSC Adv. 2016, 6, 57199-57209. [CrossRef]

37. Luengnaruemitchai, A.; Pojanavaraphan, C.; Kumyam, A.; Thunyaratchatanon, C.; Gulari, E. Hydrogen production from the oxidative steam reforming of methanol over $\mathrm{AuCu}$ nanoparticles supported on Ce1-xZrxO2 in a fixed-bed reactor. Int. J. Hydrog. Energy 2019, 44, 1686-1700. [CrossRef]

38. Lu, J.; Li, X.; He, S.; Han, C.; Wan, G.; Lei, Y.; Chen, R.; Liu, P.; Chen, K.; Zhang, L.; et al. Hydrogen production via methanol steam reforming over Ni-based catalysts: Influences of Lanthanum (La) addition and supports. Int. J. Hydrog. Energy 2017, 42, 3647-3657. [CrossRef]

39. Papavasiliou, J.; Avgouropoulos, G.; Ioannides, T. Combined steam reforming of methanol over Cu-Mn spinel oxide catalysts. J. Catal. 2007, 251, 7-20. [CrossRef]

40. Ma, L.; Gong, B.; Tran, T.; Wainwright, M.S. Cr2O3 promoted skeletal Cu catalysts for the reactions of methanol steam reforming and water gas shift. Catal. Today 2000, 63, 499-505. [CrossRef]

41. Yao, C.-Z.; Wang, L.-C.; Liu, Y.-M.; Wu, G.-S.; Cao, Y.; Dai, W.-L.; He, H.-Y.; Fan, K.-N. Effect of preparation method on the hydrogen production from methanol steam reforming over binary $\mathrm{Cu} / \mathrm{ZrO} 2$ catalysts. Appl. Catal. A Gen. 2006, 297, 151-158. [CrossRef]

42. Shen, J.-P.; Song, C. Influence of preparation method on performance of $\mathrm{Cu} / \mathrm{Zn}$-based catalysts for low-temperature steam reforming and oxidative steam reforming of methanol for $\mathrm{H} 2$ production for fuel cells. Catal. Today 2002, 77, 89-98. [CrossRef]

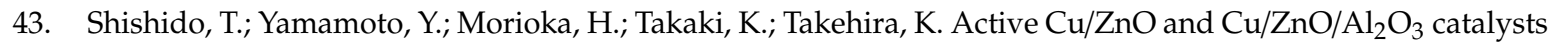
prepared by homogeneous precipitation method in steam reforming of methanol. Appl. Catal. A Gen. 2004, 263, 249-253. [CrossRef]

44. Larrubia Vargas, M.A.; Busca, G.; Costantino, U.; Marmottini, F.; Montanari, T.; Patrono, P.; Pinzari, F.; Ramis, G. An IR study of methanol steam reforming over ex-hydrotalcite $\mathrm{Cu}-\mathrm{Zn}-\mathrm{Al}$ catalysts. J. Mol. Catal. A Chem. 2007, 266, 188-197. [CrossRef]

45. Peppley, B.A.; Amphlett, J.C.; Kearns, L.M.; Mann, R.F. Methanol-steam reforming on $\mathrm{Cu} / \mathrm{ZnO} / \mathrm{Al}_{2} \mathrm{O}_{3}$ catalysts. Part 2. A comprehensive kinetic model. Appl. Catal. A Gen. 1999, 179, 31-49. [CrossRef]

46. Liu, S.; Takahashi, K.; Uematsu, K.; Ayabe, M. Hydrogen production by oxidative methanol reforming on Pd/ZnO. Appl. Catal. A Gen. 2005, 283, 125-135. [CrossRef]

47. Takahashi, K.; Takezawa, N.; Kobayashi, H. The mechanism of steam reforming of methanol over a copper-silica catalyst. Appl. Catal. 1982, 2, 363-366. [CrossRef]

48. Turco, M.; Bagnasco, G.; Costantino, U.; Marmottini, F.; Montanari, T.; Ramis, G.; Busca, G. Production of hydrogen from oxidative steam reforming of methanol: II. Catalytic activity and reaction mechanism on $\mathrm{Cu} / \mathrm{ZnO} / \mathrm{Al}_{2} \mathrm{O}_{3}$ hydrotalcite-derived catalysts. J. Catal. 2004, 228, 56-65. [CrossRef]

49. Turco, M.; Bagnasco, G.; Cammarano, C.; Senese, P.; Costantino, U.; Sisani, M. Cu/ $\mathrm{ZnO} / \mathrm{Al}_{2} \mathrm{O}_{3}$ catalysts for oxidative steam reforming of methanol: The role of $\mathrm{Cu}$ and the dispersing oxide matrix. Appl. Catal. B Environ. 2007, 77, 46-57. [CrossRef]

50. Yong, S.T.; Ooi, C.W.; Chai, S.P.; Wu, X.S. Review of methanol reforming-Cu-based catalysts, surface reaction mechanisms, and reaction schemes. Int. J. Hydrog. Energy 2013, 38, 9541-9552. [CrossRef]

51. Turco, G.; Donati, I.; Grassi, M.; Marchioli, G.; Lapasin, R.; Paoletti, S. Mechanical Spectroscopy and Relaxometry on Alginate Hydrogels: A Comparative Analysis for Structural Characterization and Network Mesh Size Determination. Biomacromolecules 2011, 12, 1272-1282. [CrossRef]

52. Turco, M.; Bagnasco, G.; Costantino, U.; Marmottini, F.; Montanari, T.; Ramis, G.; Busca, G. Production of hydrogen from oxidative steam reforming of methanol: I. Preparation and characterization of $\mathrm{Cu} / \mathrm{ZnO} / \mathrm{Al}_{2} \mathrm{O}_{3}$ catalysts from a hydrotalcite-like LDH precursor. J. Catal. 2004; 228, 43-55. [CrossRef]

53. Reitz, T.L.; Lee, P.L.; Czaplewski, K.F.; Lang, J.C.; Popp, K.E.; Kung, H.H. Time-Resolved XANES Investigation of $\mathrm{CuO} / \mathrm{ZnO}$ in the Oxidative Methanol Reforming Reaction. J. Catal. 2001, 199, 193-201. [CrossRef] 
54. Mrad, M.; Gennequin, C.; Aboukaïs, A.; Abi-Aad, E. Cu/Zn-based catalysts for H2 production via steam reforming of methanol. Catal. Today 2011, 176, 88-92. [CrossRef]

55. Sexton, B.A. Surface vibrations of adsorbed intermediates in the reaction of alcohols with $\mathrm{Cu}(100)$. Surf. Sci. 1979, 88, 299-318. [CrossRef]

56. Wachs, I.E.; Madix, R.J. The selective oxidation of $\mathrm{CH} 3 \mathrm{OH}$ to $\mathrm{H} 2 \mathrm{CO}$ on a copper(110) catalyst. J. Catal. 1978, 53, 208-227. [CrossRef]

57. Russell, J.N.; Gates, S.M.; Yates, J.T. Reaction of methanol with $\mathrm{Cu}(111)$ and $\mathrm{Cu}(111)+\mathrm{O}($ ads). Surf. Sci. 1985, 163, 516-540. [CrossRef]

58. Chinchen, G.C.; Spencer, M.S.; Waugh, K.C.; Whan, D.A. Promotion of methanol synthesis and the water-gas shift reactions by adsorbed oxygen on supported copper catalysts. J. Chem. Soc. Faraday Trans. 1 Phys. Chem. Condens. Phases 1987, 83, 2193-2212. [CrossRef]

59. Lwin, Y.; Daud, W.R.W.; Mohamad, A.B.; Yaakob, Z. Hydrogen production from steam-methanol reforming: Thermodynamic analysis. Int. J. Hydrog. Energy 2000, 25, 47-53. [CrossRef]

60. Santacesaria, E.; Carrá, S. Kinetics of catalytic steam reforming of methanol in a cstr reactor. Appl. Catal. 1983, 5, 345-358. [CrossRef]

61. Breen, J.P.; Meunier, F.C.; Ross, J.R.H. Mechanistic aspects of the steam reforming of methanol over a $\mathrm{CuO} / \mathrm{ZnO} / \mathrm{ZrO} 2 / \mathrm{Al} 2 \mathrm{O} 3$ catalyst. Chem. Commun. 1999, 2247-2248. [CrossRef]

62. Agrell, J.; Birgersson, $\mathrm{H}$.; Boutonnet, $\mathrm{M}$. Steam reforming of methanol over a $\mathrm{Cu} / \mathrm{ZnO} / \mathrm{Al}_{2} \mathrm{O}_{3}$ catalyst: a kinetic analysis and strategies for suppression of CO formation. J. Power Sources 2002, 106, 249-257. [CrossRef]

63. Mastalir, A.; Frank, B.; Szizybalski, A.; Soerijanto, H.; Deshpande, A.; Niederberger, M.; Schomäcker, R.; Schlögl, R.; Ressler, T. Steam reforming of methanol over $\mathrm{Cu} / \mathrm{ZrO}_{2} / \mathrm{CeO}_{2}$ catalysts: a kinetic study. J. Catal. 2005, 230, 464-475. [CrossRef]

64. Gallucci, F.; Paturzo, L.; Basile, A. Hydrogen Recovery from Methanol Steam Reforming in a Dense Membrane Reactor: Simulation Study. Ind. Eng. Chem. Res. 2004, 43, 2420-2432. [CrossRef]

65. Morillo, A.; Freund, A.; Merten, C. Concept and Design of a Novel Compact Reactor for Autothermal Steam Reforming with Integrated Evaporation and CO Cleanup. Ind. Eng. Chem. Res. 2004, 43, 4624-4634. [CrossRef]

66. Jiang, C.J.; Trimm, D.L.; Wainwright, M.S.; Cant, N.W. Kinetic study of steam reforming of methanol over copper-based catalysts. Appl. Catal. A Gen. 1993, 93, 245-255. [CrossRef]

67. Breen, J.P.; Ross, J.R.H. Methanol reforming for fuel-cell applications: development of zirconia-containing $\mathrm{Cu}-\mathrm{Zn}-\mathrm{Al}$ catalysts. Catal. Today 1999, 51, 521-533. [CrossRef]

68. Iwasa, N.; Kudo, S.; Takahashi, H.; Masuda, S.; Takezawa, N. Highly selective supported Pd catalysts for steam reforming of methanol. Catal. Lett. 1993, 19, 211-216. [CrossRef]

69. Amiri, T.Y.; Moghaddas, J. Reaction parameters influence on the catalytic performance of copper-silica aerogel in the methanol steam reforming. J. Fuel Chem. Technol. 2016, 44, 84-90. [CrossRef]

70. Murcia-Mascarós, S.; Navarro, R.M.; Gómez-Sainero, L.; Costantino, U.; Nocchetti, M.; Fierro, J.L.G. Oxidative Methanol Reforming Reactions on CuZnAl Catalysts Derived from Hydrotalcite-like Precursors. J. Catal. 2001, 198, 338-347. [CrossRef]

71. Rabe, S.; Vogel, F. A thermogravimetric study of the partial oxidation of methanol for hydrogen production over a $\mathrm{Cu} / \mathrm{ZnO} / \mathrm{Al}_{2} \mathrm{O}_{3}$ catalyst. Appl. Catal. B Environ. 2008, 84, 827-834. [CrossRef]

72. Patel, S.; Pant, K.K. Kinetic modeling of oxidative steam reforming of methanol over $\mathrm{Cu} / \mathrm{ZnO} / \mathrm{CeO} 2 / \mathrm{Al}_{2} \mathrm{O}_{3}$ catalyst. Appl. Catal. A Gen. 2009, 356, 189-200. [CrossRef]

73. Patel, S.; Pant, K.K. Hydrogen production by oxidative steam reforming of methanol using ceria promoted copper-alumina catalysts. Fuel Process. Technol. 2007, 88, 825-832. [CrossRef]

74. Horny, C.; Renken, A.; Kiwi-Minsker, L. Compact string reactor for autothermal hydrogen production. Catal. Today 2007, 120, 45-53. [CrossRef]

75. Horng, R.-F.; Chou, H.-M.; Lee, C.-H.; Tsai, H.-T. Characteristics of hydrogen produced by partial oxidation and auto-thermal reforming in a small methanol reformer. J. Power Sources 2006, 161, 1225-1233. [CrossRef]

76. Riva, A.; Trifirò, F.; Vaccari, A.; Mintchev, L.; Busca, G. Structure and reactivity of zinc-chromium mixed oxides. Part 2.-Study of the surface reactivity by temperature-programmed desorption of methanol. J. Chem. Soc. Faraday Trans. 1 Phys. Chem. Condens. Phases 1988, 84, 1423-1435. [CrossRef]

77. Peppley, B.A.; Amphlett, J.C.; Kearns, L.M.; Mann, R.F. Methanol-steam reforming on $\mathrm{Cu} / \mathrm{ZnO} / \mathrm{Al}_{2} \mathrm{O}_{3}$. Part 1: the reaction network. Appl. Catal. A Gen. 1999, 179, 21-29. [CrossRef] 
78. Shan, W.; Feng, Z.; Li, Z.; Zhang, J.; Shen, W.; Li, C. Oxidative steam reforming of methanol on Ce0.9Cu0.1OY catalysts prepared by deposition-precipitation, coprecipitation, and complexation-combustion methods. J. Catal. 2004, 228, 206-217. [CrossRef]

79. Papavasiliou, J.; Avgouropoulos, G.; Ioannides, T. Production of hydrogen via combined steam reforming of methanol over $\mathrm{CuO}-\mathrm{CeO}_{2}$ catalysts. Catal. Commun. 2004, 5, 231-235. [CrossRef]

80. Shishido, T.; Yamamoto, Y.; Morioka, H.; Takehira, K. Production of hydrogen from methanol over $\mathrm{Cu} / \mathrm{ZnO}$ and $\mathrm{Cu} / \mathrm{ZnO} / \mathrm{Al}_{2} \mathrm{O}_{3}$ catalysts prepared by homogeneous precipitation: Steam reforming and oxidative steam reforming. J. Mol. Catal. A Chem. 2007, 268, 185-194. [CrossRef]

81. Ritzkopf, I.; Vukojević, S.; Weidenthaler, C.; Grunwaldt, J.-D.; Schüth, F. Decreased CO production in methanol steam reforming over $\mathrm{Cu} / \mathrm{ZrO}_{2}$ catalysts prepared by the microemulsion technique. Appl. Catal. A Gen. 2006, 302, 215-223. [CrossRef]

82. Wang, C.-T.; Willey, R.J. Fine particle iron oxide based aerogels for the partial oxidation of methanol. Catal. Today 1999, 52, 83-89. [CrossRef]

83. Matsumura, Y.; Tanaka, K.; Tode, N.; Yazawa, T.; Haruta, M. Catalytic methanol decomposition to carbon monoxide and hydrogen over nickel supported on silica. J. Mol. Catal. A Chem. 2000,152, 157-165. [CrossRef]

84. Dinka, P.; Mukasyan, A. Solution combustion synthesis of nano materials. In Proceedings of the 2006 NSTI Nanotechnology Conference and Trade Show-NSTI Nanotech 2006 Technical Proceedings, Boston, MA, USA, 7-11 May 2006; pp. 456-459.

85. Liu, S.; Takahashi, K.; Ayabe, M. Hydrogen production by oxidative methanol reforming on Pd/ZnO catalyst: effects of Pd loading. Catal. Today 2003, 87, 247-253. [CrossRef]

86. Haynes, D.J.; Shekhawat, D.; Spivey, J.J.; Berry, D.A. Chapter 6-Oxidative Steam Reforming. In Fuel Cells; Elsevier: Amsterdam, The Netherlands, 2011; pp. 129-190.

87. Pijolat, M.; Prin, M.; Soustelle, M.; Touret, O.; Nortier, P. Thermal stability of doped ceria: experiment and modelling. J. Chem. Soc. Faraday Trans. 1995, 91, 3941-3948. [CrossRef]

88. Fornasiero, P.; Balducci, G.; di Monte, R.; Kašpar, J.; Sergo, V.; Gubitosa, G.; Ferrero, A.; Graziani, M. Modification of the Redox Behaviour of $\mathrm{CeO}_{2}$ Induced by Structural Doping with $\mathrm{ZrO}_{2}$. J. Catal. 1996, 164, 173-183. [CrossRef]

89. Fan, L.; Fujimoto, K. Reaction Mechanism of Methanol Synthesis from Carbon Dioxide and Hydrogen on Ceria-Supported Palladium Catalysts with SMSI Effect. J. Catal. 1997, 172, 238-242. [CrossRef]

90. Zhang, X.; Shi, P. Production of hydrogen by steam reforming of methanol on $\mathrm{CeO}_{2}$ promoted $\mathrm{Cu} / \mathrm{Al}_{2} \mathrm{O}_{3}$ catalysts. J. Mol. Catal. A Chem. 2003, 194, 99-105. [CrossRef]

91. Mierczynski, P.; Mosinska, M.; Maniukiewicz, W.; Nowosielska, M.; Czylkowska, A.; Szynkowska, M.I. Oxy-steam reforming of methanol on copper catalysts. React. Kinet. Mech. Catal. 2019, 127, 857-874. [CrossRef]

92. Iwasa, N.; Yoshikawa, M.; Nomura, W.; Arai, M. Transformation of methanol in the presence of steam and oxygen over ZnO-supported transition metal catalysts under stream reforming conditions. Appl. Catal. A Gen. 2005, 292, 215-222. [CrossRef]

93. Iwasa, N.; Masuda, S.; Ogawa, N.; Takezawa, N. Steam reforming of methanol over Pd/ZnO: Effect of the formation of PdZn alloys upon the reaction. Appl. Catal. A Gen. 1995, 125, 145-157. [CrossRef]

94. Iwasa, N.; Takezawa, N. New Supported Pd and Pt Alloy Catalysts for Steam Reforming and Dehydrogenation of Methanol. Top. Catal. 2003, 22, 215-224. [CrossRef]

95. Kapoor, M.P.; Ichihashi, Y.; Kuraoka, K.; Matsumura, Y. Catalytic methanol decomposition over palladium deposited on thermally stable mesoporous titanium oxide. J. Mol. Catal. A Chem. 2003, 198, 303-308. [CrossRef]

96. Kapoor, M.P.; Ichihashi, Y.; Kuraoka, K.; Shen, W.-J.; Matsumura, Y. Catalytic Methanol Decomposition Over Palladium Deposited on Mesoporous Cerium Oxide. Catal. Lett. 2003, 88, 83-87. [CrossRef]

97. Lenarda, M.; Moretti, E.; Storaro, L.; Patrono, P.; Pinzari, F.; Rodríguez-Castellón, E.; Jiménez-López, A.; Busca, G.; Finocchio, E.; Montanari, T.; et al. Finely dispersed Pd-Zn catalyst supported on an organized mesoporous alumina for hydrogen production by methanol steam reforming. Appl. Catal. A Gen. 2006, 312, 220-228. [CrossRef]

98. Usami, Y.; Kagawa, K.; Kawazoe, M.; Yasuyuki, M.; Sakurai, H.; Haruta, M. Catalytic methanol decomposition at low temperatures over palladium supported on metal oxides. Appl. Catal. A Gen. 1998, 171, 123-130. [CrossRef] 
99. Udani, P.P.C.; Gunawardana, P.V.D.S.; Lee, H.C.; Kim, D.H. Steam reforming and oxidative steam reforming of methanol over CuO-CeO2 catalysts. Int. J. Hydrog. Energy 2009, 34, 7648-7655. [CrossRef]

100. Serp, P.; Corrias, M.; Kalck, P. Carbon nanotubes and nanofibers in catalysis. Appl. Catal. A Gen. 2003, 253, 337-358. [CrossRef]

101. Seelam, P.K.; Huuhtanen, M.; Sápi, A.; Szabó, M.; Kordás, K.; Turpeinen, E.; Tóth, G.; Keiski, R.L. CNT-based catalysts for $\mathrm{H} 2$ production by ethanol reforming. Int. J. Hydrog. Energy 2010, 35, 12588-12595. [CrossRef]

102. Pham-Huu, C.; Keller, N.; Ehret, G.; Charbonniere, L.c.J.; Ziessel, R.; Ledoux, M.J. Carbon nanofiber supported palladium catalyst for liquid-phase reactions: An active and selective catalyst for hydrogenation of cinnamaldehyde into hydrocinnamaldehyde. J. Mol. Catal. A Chem. 2001, 170, 155-163. [CrossRef]

103. Hou, T.; Yuan, L.; Ye, T.; Gong, L.; Tu, J.; Yamamoto, M.; Torimoto, Y.; Li, Q. Hydrogen production by low-temperature reforming of organic compounds in bio-oil over a CNT-promoting Ni catalyst. Int. J. Hydrog. Energy 2009, 34, 9095-9107. [CrossRef]

104. Solhy, A.; Machado, B.F.; Beausoleil, J.; Kihn, Y.; Gonçalves, F.; Pereira, M.F.R.; Órfão, J.J.M.; Figueiredo, J.L.; Faria, J.L.; Serp, P. MWCNT activation and its influence on the catalytic performance of $\mathrm{Pt} / \mathrm{MWCNT}$ catalysts for selective hydrogenation. Carbon 2008, 46, 1194-1207. [CrossRef]

105. Tang, J.M.; Jensen, K.; Waje, M.; Li, W.; Larsen, P.; Pauley, K.; Chen, Z.; Ramesh, P.; Itkis, M.E.; Yan, Y.; et al. High Performance Hydrogen Fuel Cells with Ultralow Pt Loading Carbon Nanotube Thin Film Catalysts. J. Phys. Chem. C 2007, 111, 17901-17904. [CrossRef]

106. Liu, Z.-T.; Wang, C.-X.; Liu, Z.-W.; Lu, J. Selective hydrogenation of cinnamaldehyde over Pt-supported multi-walled carbon nanotubes: Insights into the tube-size effects. Appl. Catal. A Gen. 2008, 344, 114-123. [CrossRef]

107. Agrell, J.; Birgersson, H.; Boutonnet, M.; Melián-Cabrera, I.; Navarro, R.M.; Fierro, J.L.G. Production of hydrogen from methanol over $\mathrm{Cu} / \mathrm{ZnO}$ catalysts promoted by $\mathrm{ZrO}_{2}$ and $\mathrm{Al}_{2} \mathrm{O}_{3}$. J. Catal. 2003, 219, 389-403. [CrossRef]

108. Huang, X.; Ma, L.; Wainwright, M.S. The influence of Cr, Zn and Co additives on the performance of skeletal copper catalysts for methanol synthesis and related reactions. Appl. Catal. A Gen. 2004, 257, 235-243. [CrossRef]

109. Liu, S.; Takahashi, K.; Uematsu, K.; Ayabe, M. Hydrogen production by oxidative methanol reforming on $\mathrm{Pd} / \mathrm{ZnO}$ catalyst: effects of the addition of a third metal component. Appl. Catal. A Gen. 2004, 277, 265-270. [CrossRef]

110. Haruta, M.; Tsubota, S.; Kobayashi, T.; Kageyama, H.; Genet, M.J.; Delmon, B. Low-Temperature Oxidation of $\mathrm{CO}$ over Gold Supported on $\mathrm{TiO}_{2}, \alpha-\mathrm{Fe}_{2} \mathrm{O}_{3}$, and $\mathrm{Co}_{3} \mathrm{O}_{4}$. J. Catal. 1993, 144, 175-192. [CrossRef]

111. Mierczynski, P.; Vasilev, K.; Mierczynska, A.; Maniukiewicz, W.; Ciesielski, R.; Rogowski, J.; Szynkowska, I.M.; Trifonov, A.Y.; Dubkov, S.V.; Gromov, D.G.; et al. The effect of gold on modern bimetallic Au-Cu/MWCNT catalysts for the oxy-steam reforming of methanol. Catal. Sci. Technol. 2016, 6, 4168-4183. [CrossRef]

112. Mierczynski, P.; Ciesielski, R.; Kedziora, A.; Nowosielska, M.; Kubicki, J.; Maniukiewicz, W.; Czylkowska, A.; Maniecki, T.P. Monometallic copper catalysts supported on multi-walled carbon nanotubes for the oxy-steam reforming of methanol. React. Kinet. Mech. Catal. 2016, 117, 675-691. [CrossRef]

113. Chin, Y.-H.; Dagle, R.; Hu, J.; Dohnalkova, A.C.; Wang, Y. Steam reforming of methanol over highly active $\mathrm{Pd} / \mathrm{ZnO}$ catalyst. Catal. Today 2002, 77, 79-88. [CrossRef]

114. Cubeiro, M.L.; Fierro, J.L.G. Partial oxidation of methanol over supported palladium catalysts. Appl. Catal. A Gen. 1998, 168, 307-322. [CrossRef]

115. Cubeiro, M.L.; Fierro, J.L.G. Selective Production of Hydrogen by Partial Oxidation of Methanol over ZnO-Supported Palladium Catalysts. J. Catal. 1998, 179, 150-162. [CrossRef]

116. Xu, J.B.; Zhao, T.S.; Yang, W.W.; Shen, S.Y. Effect of surface composition of Pt-Au alloy cathode catalyst on the performance of direct methanol fuel cells. Int. J. Hydrog. Energy 2010, 35, 8699-8706. [CrossRef]

117. Manzoli, M.; Chiorino, A.; Boccuzzi, F. Decomposition and combined reforming of methanol to hydrogen: A FTIR and QMS study on $\mathrm{Cu}$ and $\mathrm{Au}$ catalysts supported on $\mathrm{ZnO}$ and $\mathrm{TiO}_{2}$. Appl. Catal. B Environ. 2005, 57, 201-209. [CrossRef]

118. Vizcaíno, A.; Carrero, A.; Calles, J. Hydrogen production by ethanol steam reforming over Cu-Ni supported catalysts. Int. J. Hydrog. Energy 2007, 32, 1450-1461. [CrossRef] 
119. Khzouz, M.; Wood, J.; Pollet, B.; Bujalski, W. Characterization and activity test of commercial Ni/Al2O3, $\mathrm{Cu} / \mathrm{ZnO} / \mathrm{Al}_{2} \mathrm{O}_{3}$ and prepared $\mathrm{Ni}-\mathrm{Cu} / \mathrm{Al}_{2} \mathrm{O}_{3}$ catalysts for hydrogen production from methane and methanol fuels. Int. J. Hydrog. Energy 2013, 38, 1664-1675. [CrossRef]

120. De Rogatis, L.; Montini, T.; Lorenzut, B.; Fornasiero, P. NixCuy/Al2O3 based catalysts for hydrogen production. Energy Environ. Sci. 2008, 1, 501-509. [CrossRef]

121. Pérez-Hernández, R.; Mondragón Galicia, G.; Mendoza Anaya, D.; Palacios, J.; Angeles-Chavez, C.; Arenas-Alatorre, J. Synthesis and characterization of bimetallic $\mathrm{Cu}-\mathrm{Ni} / \mathrm{ZrO}_{2}$ nanocatalysts: $\mathrm{H} 2$ production by oxidative steam reforming of methanol. Int. J. Hydrog. Energy 2008, 33, 4569-4576. [CrossRef]

122. Eaimsumang, S.; Chollacoop, N.; Luengnaruemitchai, A.; Taylor, S.H. Ceria nanorod supported gold nanoparticles as structured catalysts for the oxidative steam reforming of methanol: Effect of CTAB concentration on physiochemical properties and catalyst performance. J. Catal. 2020, 392, 254-265. [CrossRef]

123. Wang, C.; Liu, N.; Pan, L.; Wang, S.; Yuan, Z.; Wang, S. Measurement of concentration profiles over $\mathrm{ZnO}-\mathrm{Cr}_{2} \mathrm{O}_{3} / \mathrm{CeO}_{2}-\mathrm{ZrO}_{2}$ monolithic catalyst in oxidative steam reforming of methanol. Fuel Process. Technol. 2007, 88, 65-71. [CrossRef]

Publisher's Note: MDPI stays neutral with regard to jurisdictional claims in published maps and institutional affiliations.

(C) 2020 by the authors. Licensee MDPI, Basel, Switzerland. This article is an open access article distributed under the terms and conditions of the Creative Commons Attribution (CC BY) license (http://creativecommons.org/licenses/by/4.0/). 